University of Chicago Law School

Chicago Unbound

Journal Articles

Faculty Scholarship

1959

\title{
The Supreme Court, Congress, and State Jurisdiction over Labor Relations: I
}

Bernard D. Meltzer

Follow this and additional works at: https://chicagounbound.uchicago.edu/journal_articles

Part of the Law Commons

\section{Recommended Citation}

Bernard D. Meltzer, "The Supreme Court, Congress, and State Jurisdiction over Labor Relations: I," 59 Columbia Law Review 6 (1959).

This Article is brought to you for free and open access by the Faculty Scholarship at Chicago Unbound. It has been accepted for inclusion in Journal Articles by an authorized administrator of Chicago Unbound. For more information, please contact unbound@law.uchicago.edu. 


\title{
THE SUPREME COURT, CONGRESS, AND STATE JURISDICTION OVER LABOR RELATIONS: 1
}

\author{
BERNARD D. MELTZER*
}

The difficulties surrounding state jurisdiction over labor relations moved a thoughtful commentator, writing in 1954, to describe the situation as a "constitutional crisis." There will naturally be disagreement as to whether "crisis" was too strong a word. I believe, however, that there will be general agreement that subsequent decisions of the Supreme Court have reflected growing disorder and difficulties. The Court's opinions in International Union, UAW v. Russell ${ }^{2}$ and International Ass'n of Machinists v. Gonzales, ${ }^{3}$ which provoked sharp dissents, have recently further blurred the borderland of state competence. Accordingly, a re-examination of the Court's work in this area may be justified despite the pages of scholarship which have already been devoted to the issues involved."

\section{BACKGROUND}

An appreciation of the difficulties involved will be promoted by a reference to the familiar constitutional and statutory framework within which the Court has dealt with federal and state power over labor relations. ${ }^{5}$ Congressional power over labor relations has in general depended on the scope given to the commerce power. Under the restrictive constitutional doctrine prevailing prior to the constitutional revolution of the thirties, labor relations were in general beyond the commerce power. Prior to the enactment of the Wagner

* Professor of Law, The University of Chicago Law School. This article is a revision of a paper which was submitted to the August 1958 meeting of the Council of State Chief Justices. The revisions incorporate selected developments occurring after that meeting. An earlier and substantially similar version of this article appeared in 8 U. Chi. L.S. Record, Autumn 1958, Special Supp., p. 95.

1. Hays, Federalism and Labor Relationss in the United States, 102 U. PA. L. REV. 959, 961 (1954).

2. 356 U.S. 634 (1958) (Warren, C.J.2 and Douglas, J., dissenting; Black, J., not participating).

3. 356 U.S. 617 (1958) (with the Court divided as in Russell).

4. A far from exhaustive list of useful and comprehensive articles includes Bernstein, Complement or Confict: Federal State Jurisdiction in Labor-Managentent Relations, 3 How. L.J. 191 (1957) ; Cox, Federalism in the Law of Labor Relations, 67 HaRv. L. Rev. 1297 (1954); Cox \& Seidman, Federalism and Labor Relations, 64 Hanv. L. Rev. 211 (1950); Gregory, Constitutional Limitations on the Regulation of Union and entployer Conduct, 49 MrCH. L. REv. 191 (1950); Hall, The Taft-Hartley Act v. State Regulation, 1 J. PuB. L. 97 (1952); Isaacson, Federal Preemption Under the Taft-Hartley Act, 11 IND. \& I AB. REL. REv. 391 (1958); Petro, Participation by the States in the Enforcement and Development of National Labor Policy, 5 N.Y.U. ANN. LAB. Conf. 1 (1952); Ratner, Problems of Federal-State Jurisdiction in Labor Relations, 5 N.Y.U. ANN. LAB. CoNF. 77 (1952); Reilly, State Rights and the Law of Labor Relations, in Labor UnIons and Public PouICy 93 (1958); Rose, The Labor Management Relations Act and the State's Power to Grant Relief, 39 VA. L. REv. 765 (1953).

5. It should be noted that while state power over labor relations "affecting commerce" was being pre-empted, state power to formulate labor policy (absent commerce and pre-emption) was being expanded by the Court's reformulation and limitation of the doctrine that picketing is "free speech" protected against state regulation by the fourteenth amendment. These developments are summarized in International Bhd. of Teamsters, AFL v. Vogt, 354 U.S. 284 (1957). 
Act $^{0}$ in 1935, substantially all governmental regulation of labor-management relations (except as to instrumentalities of commerce, such as railroads and shipping lines) was state regulation. In 1937, the Supreme Court, coming to terms with a new regime of federal regulation, upheld the national authority to regulate labor relations in manufacturing enterprises and sustained the constitutionality of the Wagner Act. ${ }^{7}$

In the Wagner Act, federal power over commerce was fully exercised, in part, at least, because it had previously been given such narrow scope by the Court. After that act was sustained, each decision broadening constitutional authority under the commerce clause eularged the statutory power of the NLRB. The reach of the Board's statutory jurisdiction was thus determined by the accidents of constitutional litigation rather than by a considered judgment concerning either the desirability of extending federal labor regulation to enterprises of predominantly local character or the capacity of the national board to exercise effectively the far-reaching responsibilities conferred on it by essentially constitutional adjudication. Insofar as the recognition of federal competence operated to oust state power over matters "affecting commerce," constitutional considerations, although often fortuitous as to the proper adjustment between existing state and federal regulation, were decisive.

In the early administration of the Wagner Act, the newly confirmed federal power was for a time pressed close to its periphery. As a result, the NLRB was in danger of being swamped by a mass of cases which it considered relatively minor and which would have conscripted the time and energies necessary for the effective handling of cases which appeared to the Board to have a more siguificant impact on the national interest. In order to husband its resources, which appeared inadequate for the full exercise of its statutory authority, the Board, as a matter of administrative policy, declined on a case-by-case basis to exercise jurisdiction over small business and particular types of business, such as hotels and restaurants, which it considered essentially local in character. ${ }^{8}$

Although the reach of the Wagner Act was long, encompassing all enterprises whose impact on interstate commerce could be said to be more than de minimis, ${ }^{,}$its purpose and its prohibitions were relatively narrow. It was designed to protect the employees' freedom to choose representatives for col-

6. National Labor Relations Act, 49 Stat. 449 (1935), as amended, 29 U.S.C. $\S \S 141-67$ (1952).

7. See generally Cox, supra note 4, at 1298-1300; Hays, supra note 1, at 961-62; Stern, The Commerce Clause and the National Economy, 1933-1946, 59 HARv. L. Rev. 645, 674-82 (1946).

8. After the enactment of the Taft-Hartley Act, the Board replaced its ad hoc approach with published jurisdictional standards. See generally Note, The Discretionary Jurisdiction of the NLRB, 71 HARV. L. REv. 527 (1958).

9. See Polish Nat1 Alliance v. NLRB, 322 U.S. 643, 647 (1944) ; NLRB v. Fainblatt, 306 U.S. 601,607 (1939). 
lective bargaining and to engage in the group activity which usually precedes and accompanies such bargaining. The act implemented those purposes by proscribing employer coercion and interference with such activities and by providing for representation machinery which would register the employees' wishes.

The Wagner Act did not regulate union pressures in any way, and it was generally assumed that state competence over such matters remained.10 Nevertheless, the overtones of certain Supreme Court decisions ${ }^{11}$ suggested that the Court might curtail state competence by expansively reading the national proscription of employer interference with "concerted activities" as precluding similar interference through state regulation.

There was no occasion to resolve this problem because the enactment of the Taft-Hartley Act ${ }^{12}$ significantly changed the framework in which state power was to be defined. The purposes behind the act were much broader than those of the original NLRA. At the risk of oversimplification, three of its principal purposes may usefully be mentioned: (1) protection of employee self-determination against union, as well as employer, pressures $;^{13}(2)$ protection of employers and the public against the disruption caused by certain "bad practices" of unions; ;4 and (3) a general increase in the power of employers relative to that of unions, whose strength had grown and had been vigorously exerted during the war and postwar period. ${ }^{15}$ To achieve these purposes, the act regulated strikes, picketing, and boycotts. In addition, it sought to protect the integrity of collective bargaining agreements by proscribing pressures to nodify them during their agreed-upon term ${ }^{10}$ and by providing for their enforcement in the federal courts. ${ }^{17}$

Taft-Hartley thus laid hold of aspects of labor relations which, except for the incidental impact of the Sherman Act, had been left wholly to state regulation. Such regulation was, however, not a discrete and nicely identifiable body of law. It consisted not only of labor relations statutes, tailor-made for labor-management problems, but also of an extensive body of statutory and common law regulation of general application which impinged on such problems.

Even if Congress had been aware of the problems of federalism posed

10. See Smith, The Taft-Hartley Act and State Jurisdiction over Labor Relations, 46 MICH. L. REv. 593, 606 (1948).

11. Hill v. Florida ex rel. Watson, 325 U.S. 538 (1945); Allen-Bradley Local 1111. United Elec. Workers v. Wisconsin Employment Relations Bd., 315 U.S. 740, 750-51 (1942).

12. Labor Management Relations Act, 1947, 61 Stat. 136, as amended, 29 U.S.C. $\S \S 141-88$ (1952), as amended, 29 U.S.C. $\$ \$ 154,172$, 178, 188 (Supp. V, 1958) [hereinafter cited as LMRA].

13. See LMRA \& 1 (a).

14. See LMRA \& 8(b).

15. See Millis \& Brown, From the Wagner Act to Taft-Hartley 271-315 (1950).

16. LMRA $\$ \$ 8(\mathrm{~b})(3), 8(\mathrm{~d})$.

17. LMRA §301. 
by the act, congressional formulation of guides for allocating power would have involved formidable intellectual and political difficulties. It is reasonably clear, however, that Congress, including the principal draftsmen of the act, did not appreciate the problems involved, ${ }^{18}$ let alone the fact that the ultimate allocation between state and national authority could frustrate the purposes articulated by particular legislators and shared perhaps by a majority of them. In any event, congressional directions were, as the Court has frequently observed, fragmentary and elusive. ${ }^{19}$ As a result, there was committed to the Court the task of adjusting two intricate systems of regulation. The Court, in turn, purported to determine what Congress "intended," or what it would have "intended" if it had appreciated the problems involved, or what kind of adjustments between federal and state power made sense within the framework of the national regulation.

Such a task is always difficult, in part because of the controversy surrounding the proper role of the states under modern economic and technological conditions and also because of the difficulty of separating the issue of who should regulate from issues concerning the merits of particular regulation. In the context of labor relations, two considerations have made the latter difficulty peculiarly acute: (1) the "community," as well as unions and employers, has remained sharply divided as to the content of a wise labor policy; and (2) unions have generally urged the contraction of state power, while employers have generally urged its preservation. The Court, even assuming that it could stay above the partisan battle, could scarcely expect powerful, vocal, and disappointed interest groups to concede its detachment. Thus, the coalescence of touchy problems of federalism with controversial issues of labor policy invited and produced public misunderstanding and disparagement of the Court's work.

The Court's treatment of the problems involved can conveniently be discussed in terms of three familiar categories of conduct developed by the NLRB and the federal courts for the purpose of administering the Wagner Act and subsequently the LMRA: (1) federally protected activity; (2) federally prohibited activity; and ( 3 ) an intermediate category of activity, neither protected nor prohibited by federal law. ${ }^{20}$

18. See, e.g. 2 NLRB, Legislative History of the Labor Management Relations ACT, 1947, at 1379-80 (1948) [hereinafter cited as LEGIS. HIST.] ; Hays, supra note 1, at 965-66. But cf. H.R. Rep. No. 245, 80th Cong., 1st Sess. 40, 44 (1947), 1 Legis. Hist. 331 , 335. For a general discussion of the legislative history as it bears on pre-emption problems, see Smith, supra note 10, passim. But cf. Cox \& Seidman, supra note 4, passim.

19. Congress dealt explicitly with federalist problems in $\S 14(\mathrm{a})$, dealing with supervisors; in $\S 14(\mathrm{~b})$, dealing with state regulation of union security arrangements; in $\$ 8(\mathrm{~d})(3)$, prescribing notice of a bargaining impasse to state mediation services; and in $\S 10(a)$, prescribing the conditions for cession by the NLRB of its powers to the states.

20. Before turning to these categories, it is convenient to note that the Court has made it clear that state agencies are ousted of jurisdiction over representation cases 


\section{Federaliy Protected Activity}

The failure of the Wagner Act to regulate employee activities, its silence about state power, ${ }^{21}$ and the bitter controversy which surrounded its imposition of restraints on employer power might have been regarded as indicating that state power was not to be curtailed. State regulation, designed ostensibly at least to promote the public interest, was manifestly different from the exercise of private economic power, desigued to promote private interests. Nevertheless, Hill v. Florida ex rel. Watson ${ }^{22}$ suggested that the Wagner Act would be expansively read as excluding state, as well as employer, interference with protected activities. In that case, the Court invalidated a Florida criminal statute imposing licensing requirements on union agents and reporting requirements on unions. ${ }^{23}$ The Court, equating state interference with employer interference, concluded that Florida's restriction on the freedom of employees to choose a bargaining representative was incompatible with the declared national purpose of promoting such freedom. ${ }^{24}$ This decision was an understandable reaction to the harsh features of the Florida law, which could have been viewed as an effort to frustrate the central purpose of the national scheme. But, as Mr. Justice Frankfurter forcefully urged in dissent, there was nothing in the Wagner Act which was directed at restraining state power. Accordingly, the state regulation could have operated without "conflict" with the federal scheme. The Court's rejection of this approach and its broad rationale implied that a large body of state regnlation would be invalidated, but this implication was scarcely noticed at the time. ${ }^{25}$

"affecting commerce," without regard to whether the state criteria conflict or coincide with the pertinent federal standards. La Crosse Tel. Corp. v. Wisconsin Employment Relations Bd., 336 U.S. 18 (1949) ; Bethlehem Steel Co. v. New York Labor Relations Bd., 330 U.S. 767 (1947). See also Guss v. Utah Labor Relations Bd., 353 U.S. 1 (1957). For a discussion of the representation cases see Cox \& Seidman, supra note 4, at $212-18$; note 44 infra. at 606 .

21. The committee reports also are silent on this issue. See Smith, supra note 10,

22. 325 U.S. 538 (1945).

23. The Court recently invoked the fourteenth amendment rather than pre-emption to invalidate a similar but harsher local regulation. Staub v. City of Baxley, 355 U.S. 313 (1958).

24. As Mr. Chief Justice Stone argued in his partial dissent, this consideration did not justify the invalidation of the Florida requirement for annual reports by labor organizations, giving the names and addresses of officers and the location of offices. The Court, although conceding that this requirement was compatible with the national scheme, invalidated it on the curious ground that the imposition of punishment for noncompliance would create an obstacle to collective bargaining. 325 U.S. at 543 . A reductio ad absurdum of this argument would be a holding that state criminal laws against theft of union property, although not in conflict with the federal act, could not be enforced against union officials because imprisonment of union officials would interfere with the employees' free choice of their bargaining representative.

25. The dim future for state regulation was recognized, however, in Note, State Regulation of Labor Unions, 55 YALE L.J. 440, 445 (1946). 
After the passage of Taft-Hartley, the opponents of state power could urge, first, that Hill $v$. Florida, which had not been disturbed by Congress, ${ }^{26}$ precluded state regulation of "protected activities" and, secondly, that congressional regulation of certain forms of union conduct excluded supplementary as well as parallel state regulation. ${ }^{.27}$

In International Union, UAW v. Wisconsin Employment Relations Bd., ${ }^{28}$ the so-called Briggs-Stratton case, the Court considered only the question raised by the first of these contentions as the substantial one. ${ }^{29}$ Perhaps this emphasis arose from the fact that the case had come before the state board when only the Wagner Act, which did not regulate union practices, was in effect. The Wisconsin order was, however, to continue in effect after the enactment of the LMRA; accordingly, the Court considered the order in relation to both statutes.

The Wisconsin order challenged in Briggs-Stratton had restrained unannounced and intermittent work stoppages called by a union, without any disclosure of the union's demands, during negotiations for a new contract. Speaking through Mr. Justice Jackson, the Court, in a five to four decision, rejected the broad argument that Congress had completely ousted state power over labor relations. It accepted, however, the narrower contention that the states were precluded from prohibiting conduct protected by federal law, and it declared generally that the states could reach only employee conduct which was neither federally protected nor prohibited. The Court indicated, moreover, that the states could declare conduct illegal because of the methods involved, ${ }^{30}$ but that they could not outlaw the purposes of union or employee conduct solely on the ground that they were pursued by concerted action. ${ }^{31}$

26. In a supplemental Senate report on the bill which after amendment became the LMRA, the late Senator Taft referred to Hill $v$. Florida as posing important questions of accommodating federal and state legislation. See S. REP. No. 105, 80th Cong., 1st Sess. 6 (1947), 1 LEGrs. HIST. 412. This reference occurred in connection with a discussion of whether the federal act would permit a union shop in states illegalizing such arrangements. Subsequently, the union security problem was dealt with by a specific recognition of state power in $\$ 14(\mathrm{~b})$ of the IMRA.

27. See Ratner, supra note 4, at 82, 94-95. But cf. Petro, supra note 4.

28. 336 U.S. 245 (1949).

29. Id. at 252. It should be noted that in Briggs-Stratton and in all of the cases prior to Guss v. Utah Labor Relations Bd., 353 U.S. 1 (1957), the Court, in invalidating state regulation, carefully noted that the enterprise involved was one over which the NLRB would customarily exercise jurisdiction. The Guss case obliterated any distinction based on the Board's declination of its statutory jurisdiction. See notes 170-87 infra and accompanying text.

30. This statement was supported by the assertion that the federal act proscribed strikes only because their objectives, as distingnished from their means, were illegal. 336 U.S. at 253 . That assertion was plainly in error. See United Constr. Workers v. Laburnum Constr. Corp., 347 U.S. 656 (1954); LMRA \$ 8(b) (1) (A).

31. 336 U.S. at 257-58. But see Weber v. Anheuser-Busch, Inc., 348 U.S. 468, 480 (1955). See also Cox, The Right to Engage in Concerted Activities, 26 IND. L.J. 319, 336-37 (1951), suggesting that this limitation was designed to avoid encroachment on concerted activities through the illegal purpose test. It should be noted that insofar as state proscription of purposes rests on their incompatibility with the LMRA, the basic evils inherent in judicial policy-making via "illegal purpose" are obviated. 
Concluding that the "quickie strike" was a "coercive" method which was neither federally protected nor prohibited, ${ }^{32}$ the Court sustained the Wisconsin order.

The general approach reflected in Briggs-Stratton became the basis for a unanimous decision in International Union, $U A W$ v. O'Brien, ${ }^{33}$ which invalidated a Michigan statute prescribing a favorable employee strike vote and a waiting period as prerequisites for strike action. The decisive consideration was that

in the National Labor Relations Act ... Congress safeguarded the exercise by employees of "concerted activities" and expressly recognized the right to strike. It qualified and regulated that right in the 1947 Act ... . None of these sections can be read as permitting concurrent state regulation of peaceful strikes for higher wages. Congress occupied this field and closed it to state regulation .... Even if some state legislation in this area could be sustained, the particular statute before us could not stand. For it conflicts with the federal Act. $^{34}$

In Amalgamated Ass'n of Street Employees v. Wisconsin Employment Relations Bid, ${ }^{35}$ the Court made it clear that not even the most pressing state interest would open the door to state regulation of peaceful strikes for higher wages. It invalidated a Wisconsin statute prohibiting strikes and lockouts and requiring compulsory arbitration in connection with certain disputes involving public utilities. The Court's opinion not only relied on the conflict between the Wisconsin regulation and the federal protection of the right to strike for higher wages, but also urged that Congress, by imposing certain restrictions on strikes, had "closed to state regulation the field of peaceful strikes in industries affecting commerce." 36 It was not clear, however, whether the Court was suggesting the complete ouster of state power over peaceful strikes even in the absence of an encroachment on protected activities. ${ }^{37}$

The dissenters urged weighty objections against the Court's holding. The states had traditionally subjected utilities to broad and special regulation not applicable to other industries. There was nothing in the federal act which implied the ouster of state power to deal with emergencies "economically and

32. In view of the suggestion in Weber v. Anheuser-Busch, Inc., 348 U.S. 468 (1955), discussed in text accompanying notes 54-56 infra, that the possibility that conduct is federally prohibited excludes state action, it should be noted that similar harassing tactics during negotiations were subsequently held by the NLRB to be in violation of LMRA \$8(b) (3). Textile Workers, 108 N.L.R.B. 743 (1954), enforcement denicd, 237 F.2d 409 (D.C. Cir. 1955), cert. granted, 350 U.S. 1004, cert. vacated, 352 U.S. 864 (1956).

33. 339 U.S. 454 (1950).

34. Id. at 456-58. (Emphasis added and footnote omitted.) It is not entirely clear from this passage whether the Court was relying on "confiict" or "occupation of the field." In the last paragraph of the opinion, the Court highlighted the conflict theme by referring to the Briggs-Stratton principle as "controlling." Id. at 459.

35. 340 U.S. 383 (1951).

36. Id. at 394 .

37. See id. at 388-89. 
practically confined within a State."38 On the contrary, the federal provisions for national emergency strikes implied state power to deal with comparable local situations beyond the reach of those provisions. ${ }^{39}$

It should be noted that the Court's sanction of state power over "violence" on the picket line was in sharp contrast to its denial of state power to maintain the flow of essential services. ${ }^{40}$ Plainly, a breakdown in such services could enormously increase and complicate the problem of preserving order. Furthermore, such a breakdown posed at least as serious a problem for local authorities as a breach in the etiquette of picketing.

The considerations supporting state competence over public utility disputes, regardless of their persuasiveness, were irrelevant under the formula approved in O'Brien. Adherence to that formula would achieve a measure of predictability, but the formula plainly had the defects of its virtue. It necessarily excluded any attempt to balance the interests at stake, such as the nature and importance of the state interest involved, the impact of the challenged state regulation on the principal objectives of the national scheme, and the siguificance of the regulatory gap left by the ouster of state regulation and by the inapplicability of comparable national regulation to a local problem which local authorities reasonably considered to be acute. The exclusion of such considerations gave decisive effect to an abstract formula even though such a formula could not be supported in terms of either a plainly expressed legislative purpose $\mathrm{e}^{41}$ or the consequences produced in concrete situations. ${ }^{42}$

\section{Federally Prohibited Activity}

Where state preventive remedies reached activities which were (or might be) prohibited by federal law, the Court ousted state power on the basis of three interrelated considerations: (1) state enforcement of parallel prohibitions would interfere with centralized and expert administration of the na-

38. Id. at 407 (Frankfurter, J., dissenting).

39. The Amalganated decision seems to have been misunderstood in State v. Local 8-6, Oil Workers, 317 S.W.2d 309 (Mo. 1958). The Missouri Supreme Court upheld an injunction barring a continuation of a strike against a gas utility seized by the Governor, pursuant to the King-Thompson Act, in order to protect public health and welfare. The court distinguished Amalgamated on the ground that the Missouri statute did not provide for compulsory arbitration. This distinction plainly iguored the encroachment on protected activities resulting from the injunction against a peaceful economic strike. A more persuasive distinction would have resulted from treating the state as the employer, thereby excluding the employees from the protection of the LMRA. See IMRA $\$ \S 2(2), 2(3)$; cf. United States v. UMW, 330 U.S. 258 (1947). The overhanging threat of and the actual use of seizure after a bargaining impasse may be invalidated as contrary to the federal protection of collective bargaining. Nevertheless, the expedient of temporary government seizure coupled with exclusion of the employees involved from LMRA protection offers an escape from the grave difficulties produced by the Amalgamated decision.

40. Cf. 340 U.S. at 404 (Frankfurter, J., dissenting). See also notes 81-112 infra and accompanying text.

41. See Hays, supra note 1, at 964-66 (urging that the Court misinterpreted the congressional intent on which it so heavily relied).

42. For a less controversial applieation of Briggs-Stratton, see UMW v. Arkansas Oak Flooring Co., 351 U.S. 62 (1956), which invalidated, as a restraint on protected 
tional act by the NLRB and would create the "conflict" inherent in overlapping remedies and successive state and federal adjudication of the same conduct; (2) the line between protected and prohibited conduct is so indistinct that state regulation of conduct which might be proscribed by the LMRA involves the risk of curtailing activity which might be protected under the federal act; and (3) the federal act by regulating only certain forms of conduct implies that related forms of conduct are to be free from other sources of restraint. It should be noted that state power was denied only with respect to injunctive relief against peaceful conduct and that different questions are raised both by state injunctions against violence or intimidation and by state damage actions whether for violent or peaceful activity.

The exclusion of parallel state relief began with Plankinton Packing Co. v. Wisconsin Employment Relations Bd. ${ }^{43}$ The Court, in a cryptic per curiam opinion, ${ }^{44}$ invalidated a Wisconsin order requiring an employer to reinstate an employee with back pay because of a discriminatory discharge which had violated both the Wisconsin act and the LMRA. In a later case, the Court chose to explain Plankinton on extremely broad grounds, stating:

Section 7 of the Labor Management Relations Act not only guarantees the right of self-organization and the right to strike, but also guarantees to individual employees the "right to refrain from any or all of such activities", at least in the absence of a union shop or similar contractual arrangement applicable to the individual. Since the N. L. R. B. was given jurisdiction to enforce the rights of the employees, it was clear that the Federal Act had occupied this field to the exclusion of state regulation. Plankinton and O'Brien both show that states may not regulate in respect to rights guaranteed by Congress in $\$ 7.45$

activities, a state injunction against recognition picketing by a union with majority support, notwithstanding the union's noncompliance with the filing requirements of the LMRA. Mr. Justice Frankfurter dissented.

43. 338 U.S. 953 (1950).

44. The opinion cited La Crosse Tel. Corp. v. Wisconsin Employment Relations Bd., 336 U.S. 18 (1949), and Bethlehem Steel Co. v. New York State Labor Relations Bd., 330 U.S. 767 (1947). In these two cases, the Court had recognized the NLRB's exclusive jurisdiction over representation questions in any business subject to the Board's effective jurisdiction. Since a state decision, even though based on criteria consistent with the federal criteria, might establish a representation pattern incompatible with federal policy, and since such patterns have continuing consequences under the federal act, the Court in La Crosse found "the situation too fraught with potential conflict to permit intrusion of the state agency, even though the National Board had not acted in the particular [case] ....336 U.S. at 25. The Court's summary reliance on these cases ignored the problems raised both by the explicit recognition in LMRA $\$ 14(\mathrm{~b})$ of state competence over union security arrangements and by the legislative history of that subsection, which suggested that state jurisdiction over such arrangements was not to be impaired. See notes 125-47 infra and accompanying text.

45. Amalgamated Ass'n of St. Elec. Ry. Employees v. Wisconsin Employment Relations Bd., 340 U.S. 383, 390 n.12 (1951). Mr. Justice Frankfurter interpreted Plankinton as involving an overlap of federal and state unfair labor practices. Id. at 402 (dissenting opinion). 
Thus, $O^{\prime} B$ rien, which had denied state power to curtail section 7 rights, was invoked to bar state power to enforce those rights.

In Garner $v$. Teamsters Union, ${ }^{46}$ one theme, and perhaps the dominant one, in the Court's opinion implied the complete ouster of state authority over peaceful union conduct without regard to its classification. But the Court in a confusing departure from its own premises also indicated that in some circumstances the states retained authority over conduct neither protected nor prohibited by the national statute. Garner, because it is the leading pre-emption case and because of its obscurities, merits extended discussion.

In Garner, the Teamsters had picketed a trucking company, apparently for recognition. Although the company had not objected to unionization, the Teamsters had recruited only four of its twenty-four employees before the picketing began. The picketing, which had resulted in a drastic decline in the company's business, had been enjoined as a violation of the Pennsylvania Labor Relations Act. The Pennsylvania Supreme Court had reversed on the ground that the alleged union conduct also constituted a federal unfair labor practice and that the federal remedy was adequate and exclusive. ${ }^{47}$ One dissenter had rejected this position for practical reasons, namely, that the federal remedy was inadequate because the slow processes of the national board could not prevent imminent and irreparable harm to the employer. The Supreme Court affirmed the denial of state jurisdiction in an opinion by Mr. Justice Jackson.

The Court cited Briggs-Stratton (also written by Mr. Justice Jackson) with approval but distinguished it on the ground that Garner did not involve "injurious conduct" which either is "governable by the State or ... is entirely ungoverned." 48 The Court emphasized that the national statute in language almost identical to that of the Pennsylvania provision had proscribed the union coercion involved. Nevertheless, the Court explicitly refrained from finding a violation of the federal act because "the duty of primary decision lies with the Board."49

The emphasis on the probable illegality of the union's conduct together with the continued vitality given to Briggs-Stratton suggests that Garner could be narrowly interpreted as merely invalidating state regulation which parallels the federal act. Indeed, it was so interpreted in Weber v. AnheuserBusch, Inc..$^{50}$ and in United Constr. Workers v. Laburnum Constr. Corp. ${ }^{51}$ It may be noted in passing, however, that the Court's conclusion that a

46. 346 U.S. 485 (1953).

47. $373 \mathrm{~Pa} .19$, 94 A.2d 893 (1953).

48. 346 U.S. at 488.

49. Id. at 489 .

50. See 348 U.S. 468, 475, 479 (1955).

51. 347 U.S. $656,663,665$ (1954). 
federal violation was involved was not justified by the record tested by the Board's precedents. ${ }^{52}$

\section{Actrvity Neither Protected Nor Prohibited}

Under the narrow interpretation of Garner, union action, if it were classified as neither protected by section 7 nor prohibited by section 8, would be subject to state power in accordance with the Briggs-Stratton dictum. State boards and courts would determine the facts, and if they classified the conduct involved as "ungoverned" by federal law, they would apply state law. The propriety of this classification, on which state,jurisdiction would turn, would be subject to ultimate review by the Supreme Court.

Such an interpretation is, however, inconsistent with the importance attached by the Court to "primary interpretation" by the NLRB. In the absence of such interpertation, the Court was unwilling to rule directly on the legality of the union's conduct under the national act. Such unwillingness would in general disable the Court from disposing of federal questions raised by a claim of state encroachment on federally protected or prohibited conduct. Except for the unlikely situation where the Board had previously characterized the conduct involved as neither protected nor prohibited, such state encroachments conld be avoided ouly by foreclosing state power over conduct "ungoverned" by federal law as well as over federally prohibited or protected conduct.

The comprehensive ouster of state power necessary to protect "primary interpretation" was also implied by language in Garner suggesting that for the purpose of determining state power there were only two relevant categories of conduct, namely prohibited and protected:

The detailed prescription of a procedure for restraint of specified types of picketing would seem to imply that other picketing is to be free of other methods and sources of restraint. For the policy of the national Labor Management Relations Act is not to condemn all picketing but only that ascertained by its prescribed processes to fall within its prohibitions. Otherwise, it is implicit in the Act that the public interest is served by freedom of labor to use the weapon of picketing. For a state to impinge on the area of labor combat de-

52. The Supreme Court's intimation in Garner that the union's conduct violated $\$ 8$ (b) (2), 346 U.S. at 488-89, apparently resulted from the parties' stipulation to that effect. See Brief for Respondent, p. 15; Brief for Petitioner, pp. 15, 84. That stipulation was, however, not justified by the record read in the light of the NLRB precedents, under which a finding of a $\$ 8(\mathrm{~b})(2)$ violation would have been justified only if the picketing had been directed at achieving a closed or union shop. But there had not been any allegation of that purpose, and the Chancellor had found that the union had been engaged in organizational picketing and that it had not requested recognition, let alone a union shop. Record, vol. 50, pp. 4a-7a, 173a, 174a, 176a, 187a. Minority picketing, whether for recognition or organizational purposes, had not been held to be an unfair labor practice under the federal act. See Comment, Federal Versus State Jurisdiction Over Stranger Picketing, 20 U. CHI. L. REv. 109, 112-13 (1952). 
signed to be free is quite as much an obstruction of federal policy as if the state were to declare picketing free for purposes or by methods which the federal Act prohibits..$^{\mathbf{5 3}}$

The foregoing implication of the total ouster of state power is plainly incompatible with the result and the approach in Briggs-Stratton, where, it will be recalled, the Court appraised the union conduct prior to a Board determination and granted the same latitude to a state agency. Accordingly, despite the Court's continued approval of that case, it appears to be a doubtful basis for state competence over unprohibited and unprotected conduct.

Weber $v$. Anheuser-Busch deepened the uncertainties produced by Garner. Weber arose from an old work assignment dispute between machinists and millwrights. During negotiations for a 1952 contract, the machinists had requested that the company agree to give certain repair work on its machinery only to contractors under contract with their union. A similar clause had been in and out of earlier agreements, with its status presumably dependent on the company's response to the pressures of the rival unions. In the 1952 negotiations, the millwrights' protests led the company to reject the machinists' demand. The machinists thereupon struck and picketed the company's premises. A detailed statement of the subsequent litigation will highlight the uncertainties and the practical obstacles involved in applying the primary jurisdiction approach described in Garner and Weber.

The company promptly charged before the NLRB that the machinists had violated subsection 8 (b) (4) (D) of the LMRA. Seven months later, the NLRB quashed a notice of hearing on the ground that there had been no violation of that subsection. Somewhat less than two weeks after its resort to the NLRB, the company sought a state court injunction, alleging that the machinists had violated the common law prohibitions against secondary boycotts as well as three provisions of section 8 of the LMRA, 8(b)(4)(A), (B), and (D). After the issuance of a temporary injunction, the company amended its complaint to allege also that the machinists had been guilty of a restraint of trade in violation of the Missouri common law and statutes. More than a year after the NLRB had determined that $8(b)(4)(D)$ had not been violated, the Missouri Supreme Court upheld the permanent injunction. The United States Supreme Court reversed in a unanimous opinion by Mr. Justice Frankfurter.

The Court referred to the possibility that the machinists, as alleged by the company in the state courts, had violated subsections 8(b)(4)(A) and (B) of the LMRA. Those possibilities, the Court emphasized, had not been ruled on by the NLRB, which had negatived only the alleged violation of a different subsection. If the Board had also ruled.against a claimed violation

53. 346 U.S. at 499-500. (Emphasis added.) 
of the other subsections, "we would have a different case." "w4 But Garner had indicated that the hypothetical case would not be different, by suggesting that conduct free from federal regulation could not properly be subject to state restrictions. Plainly the hypothetical case would be different only if the Court repudiated that suggestion. In Weber, such repudiation was implied by language suggesting that pre-emption would operate only when the conduct involved is, or may reasonably be deemed to be, either federally prohibited or federally protected. ${ }^{55}$ Weber may thus be read as recognizing state power over cases involving conduct which is clearly not protected and clearly not prohibited, i.e., Weber would permit some departures from "primary interpretation" by the NLRB. Weber would curtail somewhat the state competence sanctioned by Briggs-Stratton ${ }^{5 B}$ but would extend it beyond the narrow limits suggested by Garner. This interpretation gains additional support from the Court's sympathetic reference to the difficulties surrounding state court determination as to the protected or prohibited character of concerted activities. ${ }^{57}$ Such difficulties would exist only if the states retain some jurisdiction over conduct which falls within the intermediate category.

The uncertainties and difficulties generated for state courts and for counsel by these cases scarcely need elaboration. Notwithstanding Garner, state competence may survive if the Board's General Counsel issues a complaint and if the Board's rulings negative every possibility (or every reasonable or plausible possibility) that the conduct complained of is prohibited by federal law. But even such rulings will not destroy the possibility that the conduct involved is protected. Perfect avoidance of that

54. 348 U.S. at 478.

55. [E]ven if it were clear that no unfair labor practices were involved, it would not necessarily follow that the State was free to issue its injunction. If this conduct does not fall within the prohibitions of $\S 8$ of the Taft-Hartley Act, it may fall within the protection of $\$ 7$, as concerted activity for the purpose of mutual aid or protection.

Id. at 478-79. See also id. at 479, 481. "Concerted activity," as used above, apparently refers to activity protected against employer reprisal and not, as Garner suggested, to activity not subject to federal prohibition. This interpretation is reinforced by the Court's statement, by Mr. Justice Frankfurter, in Algoma Plywood \& Veneer Co. v. Wisconsin Employment Relations Bd., 336 U.S. 301, 313 (1949): "Where the State and federal laws do not overlap, no cession is necessary beeause the State's jurisdiction is unimpaired."

The Weber opinion also emphasized that the plaintiff had alleged in the state proceedings that the conduct complained of was a federal unfair labor practice. 348 U.S. at 479,481 . Such an allegation was, moreover, considered controlling in Local 25, International Bhd. of Teamsters v. New York, N.H. \& H.R.R., 350 U.S. 155, 161 (1956). Under the broad implications of Garner, such allegations would be of no importance since the states would be excluded regardless of state overlap with federal remedies or state encroachment on activities protected by $\$ 7$ of the LMRA. Perhaps the limitation of Garner implicit in some portions of Weber moved Mr. Justice Black, an exponent of broad pre-emption in the area of labor relations, to concur in the result only.

56. Weber did not, however, refer to the intimation in Briggs-Stratton that the states were limited to regulating the means, rather than purposes, of union conduct. See text accompanying note 30 supra. Since the union indulged in a peaceful strike, that limitation, if controlling, would have disposed of the case.

57. For similar expressions, also by Mr. Justice Frankfurter, see Amalgamated Clothing Workers v. Richman Bros., 348 U.S. 511, 516 (1955). 
possibility would require an adjudication by the national board that the conduct complained of is not protected. But the Board's dismissal of a charge, although it generally discloses that the conduct is not prohibited, at least by the statutory provision specifically invoked, does not necessarily disclose whether the conduct is protected. There is, moreover, no possibility of securing a Board adjudication as to whether many significant and questionable frims of umion pressure are "protected." The category of protected conduct has been elaborated under the NLRA and the LMRA for the purpose of insulating certain forms of concerted employee action against employer interference and reprisal. The NLRB, accordingly, is not faced with the need of adjudicating whether particular conduct is protected absent an employment relationship and a complaint about employer interference with such a relationship. Thus, where, as in Garner, an employer complains about stranger picketing, the concept of activities protected by section 7 is not directly applicable.58 It would be applicable if a few employees had participated in minority picketing and had been discharged. But even if the General Counsel issued a complaint, a Board ruling as to the protected status of the employee picketing would usually involve such delay as to make any theoretical state preventive jurisdiction valueless for most practical purposes.

The foregoing considerations show that the labor-management area is not appropriate for the application of a concept of "primary jurisdiction," i.e., a requirement of prior NLRB determinations in particular cases which in turn would fix the limits for state action. It is the suggestion of such a concept by some passages of Garner and Weber which accounts for much of the extraordinary confusion produced by these cases-confusion which is accentuated by the Court's continued approval of Briggs-Stratton despite its obvious incompatibility with "primary interpretation and application" by the NLRB. Such interpretation plainly cannot be preserved, if state tribunals are to be authorized to interpret the national standards in the first instance. And the obstacles to securing NLRB adjudications prior to state action suggest that the NLRB's interpretation, if it is to be primary, must in most cases also be exclusive. Guss, ${ }^{50}$ Fairlaren, ${ }^{60}$ and $S a x^{61}$ point to such exclusiveness and its corollary, complete pre-emption of state power.

58. That concept is indirectly applicable because employees who participate in conduct which constitutes an unfair labor practice by a union are normally divested of statutory protection vis-à-vis their employer.

59. Guss v. Utah Labor Relations Bd., 353 U.S. 1, 10 (1957).

60. Amalgamated Meat Cutters, AFL v. Fairlawn Meats, Inc., 353 U.S. 20, 24 (1957), where the Court declared that "Congress did not leave it to state labor agencies, to state courts or to this Court to decide how consistent with federal policy state law must be. The power to make that decision in the first instance was given to the National Labor Relations Board ....."

61. Hotel Employees Únion v. Sax Enterprises, Inc., 358 U.S. 270, 271 (1959), a per curiam opinion, in which the Court, after reversing Florida injunctions against peaceful 
Such pre-emption has been supported not only to avoid a wholly unsuitable "primary jurisdiction" concept but also on two related grounds. First, the prohibitions of the federal act have struck a balance between contending forces. Congress in determining what was to be prohibited was also concerned with conduct which was to be free. Accordingly, additional state limitations on freedom of action through prohibitions on unions or employers would destroy that balance and would therefore be inconsistert with the federal policy. ${ }^{62}$ Secondly, the uniform regulation of labor relations which can be achieved only by the ouster of state regulation would be desirable as a matter of policy.

The balance metaphor, insofar as it purports to reflect the legislative purpose assumes a critical question, i.e., whether it is reasonable to impute to Congress the purpose of completely pre-empting state power. The most detached advocates of complete pre-emption will concede that there is no clear evidence of such a purpose. ${ }^{63}$ On the contrary, it is extremely unlikely that the architects of Taft-Hartley sanctioned such a far-reaching alteration in the federalist balance or would have done so if they had been aware of the possibility of such a result. Their basic philosophy, after all, essentially favored "states' rights." Furthermore, when the issue of state power was raised on the floor, the debate generally appeared to be based on the assumption that state power survived. ${ }^{64}$ Finally, the architects of the act were astounded by some of the results wrought in the name of the legislative purpose. ${ }^{65}$

In view of the inconclusiveness, to say the least, of the legislative history, obliteration of state power would appear to be justified only by strong considerations of policy. Even if agreement could be reached on the existence of such considerations, there would remain the familiar question as to whether the Court should maintain state power until Congress plainly ealls for its obliteration.

"organizational" picketing, declared that state jurisdiction was ousted "whether it [the picketing] was activity protected by $\S 7$... or prohibited by $\S 8(\mathrm{~b})(4)$ of the Act . ..." Since previous decisions foreclose state power over both prohibited and protected activities, the quoted statement is not very meaningful unless the Court "intended" that statement to be read as if the words "or not" preceded "whether," thus indicating the ouster of state power over activities neither protected nor prohibited.

62. See, e.g., Cox, supra note 4, at 1318-19; Ratner, supra note 4, at 97-98.

63. See, e.g., Cox, supra note 4, at 1314-15. But see Isaacson, stipra note 4, at 392-93.

64. See, e.g., 2 LEGIS. HIST. 1019-20, 1195, 1208, 1379-80; Hays, sipra note 1, at 964-65. But cf., e.g.s 2 LEGIS. HIST. 1561 (Senator Morse challenged $\$ 14$ (b) and urged a national policy with respect to union security arrangements) i H.R. REP. No. 245, 80th Cong., 1st Sess. (1947), 1 LEGIS. HIsT. 331. It is also worth noting that opponents of the legislation objected on the ground that it increased the power of the federal government. Such criticism was couched in terms of encroachment on or duplication of traditional state power, not in terms of displacing it. See 1 LEGIS. HIst. 356; 2 id. 1258, 1261-62, 1266, 1385.

65. See Hays, supra note 1 , at 965-66. 
The case on policy grounds for comprehensive pre-emption emphasizes the following considerations : ${ }^{68}$

(1) State power may frustrate the development and implementation of the national policy. Labor relations are part of a continuous human relationship; intervention at one point inevitably affects the whole process.

(2) State competence would destroy the uniformity and convenience which are part of the justification for national legislation. It would invite competition among the states in drafting "pro-management laws" to attract industry.

(3) It is desirable to avoid the difficulties inherent in interpretation by state tribunals of a complex and swiftly changing body of national regulation as well as the fine lines of distinction inherent in preserving some areas of state competence.

(4) The federalist values of local autonomy, diversity, and experimentation can be fostered by withdrawing the labor relations of smaller enterprises from the NLRB's jurisdiction and leaving their regulation exclusively to the states.

Appraisal of such considerations will obviously involve judgments or predilections about the contemporary role of state power, as well as judgments about the coherence and gaps in the particular federal legislation which is urged as the basis for state supersession. There is plainly no formula which will yield the proper appraisal. Several general comments may, however, sharpen the issues involved. In a society with a federalist tradition, the "uniformity" which is part of the justification for federal regulation consists of two extremely different kinds of uniformity. First, there is the uniformity which results when the national power is exercised to enforce minimal standards of conduct within the sphere of the national interest. Secondly, there is the uniformity which can be achieved only by an exclusive system of national regulation. Plainly, the first type of uniformity does not theoretically involve total pre-emption of state power; for regardless of whether or how the states act, they are precluded only from action which is inconsistent with the mininuum national standards. In practice, there will, of course, be acute controversy as to whether particular state regulation "conflicts" with such standards. And to the extent that the states are in error as to the existence of "conflict," there will be an impairment of national purposes, an impairment which cannot be fully corrected by Supreme Court reversals. But unless federal regulation in any context is, contrary to our tradition, ${ }^{67}$ to destroy state competence, in each case the values of preserving "consistent" state power, i.e., the values

66. See Cox, supra note 4 , at 1315-21. 435 (1953). 
of federalism, must be balanced against the danger of deranging the federal scheme. The fact that different aspects of labor relations are interrelated does not materially help in striking that balance because similar interrelationships exist in connection with almost any activity subject to federal regulation.

Nor does the objective of excluding competition in the enactment of "proemployer legislation" justify total state pre-emption. This question cannot usefully be decided as an abstraction without regard to gaps ${ }^{68}$ in the federal scheme which state action might fill in such a way as to implement the basic federal purposes. Furthermore, the objective of avoiding competition through variations in state law could be achieved only by displacing a vast body of state law of general application which impinges on labor relations. Even the most ardent pre-emptionists shrink from the regulatory gaps flowing from such an attrition of state power. ${ }^{69}$ Nevertheless, general regulations, such as laws concerning safety, health, maximum hours for women, and hiring practices, probably have at least as strong an impact on interstate rivalry for new businesses as does the regulation of activities neither prohibited nor protected by the national law. The same point may be even more important in connection with differences in local taxes. Finally, competition through legal differences which are compatible with nationally prescribed minima is merely another way of describing the characteristic values, complexities, and costs of a federal scheme.

No one who has wrestled with the Court's decisions in this area can be unsympathetic to the objective of reducing "fine lines of distinction." At the same time, no one bred in the common law tradition can ignore the need for discriminating distinctions directed at achieving some rational development of statutory and social purposes. ${ }^{70}$ Whether particular lines of distinction will succeed in achieving such purposes or whether they are worth the cost are debatable questions. But able commentators, such as Professor Cox, who have espoused a broad pre-emption of state power, in part to avoid fine distinctions,

68. There is an obvious danger of resolving pre-emption questions by labelling the IMRA as a "complete code" or as "interstitial." Although the latter label is, I believe, justified by the gaps and incongruities in the statute which are discussed below, able commentators, such as Professor Cox and Mr. Isaacson, prefer the former label.

69. See, e.g., Ratner, supra note 4, at 104-10; cf. Local 24, Int'1 Bhd. of Teamsters, AFL-CIO v. Oliver, 358 U.S. 283, 297 (1959), discussed in note 162 infra, which suggests that local health and safety regulation will not be pre-empted.

70. "Statutory purposes" in this context obviously involves the risk of questionbegging. If the LMRA is viewed as a "complete code" of regulation, any purpose which it fails to achieve is, by definition, not a "statutory purpose." But such verbalism should be rejected because the LMRA does not realize certain purposes which can be fairly characterized as central to the national scheme. For example, minority-recognition picketing, even though it is held lawful under the statute, produces results incompatible with the basic statutory purposes. See discussion in text accompanying notes 120-24 infra. Accordingly, state action which avoids such incongruous results ean be fairly said to achieve federal purposes. 
have nevertheless proposed limitations on pre-emption, which necessarily involve such distinctions. ${ }^{71}$ Such limitations make it clear that our system has recognized values beyond the quiet life for iudges and lawyers.

Finally, an attempt to compromise between the uniformity which flows from a single source of regulation and the diversity of the federalist idea, by according to the states exclusive control over the labor relations of smaller enterprises, is not without its difficulties. It may be a rough and ready way of exempting small businesses from the burdens of federal regulation and, at the same time, reducing the regulatory burdens of the national government. But such exemption frequently ignores that the fundamental purpose of national regulation is to insure the observance of minimum standards where the national interest is involved. The size of a particular business-or of its interstate transactions-is plainly a mechanical formula for determining the existence of a national interest and the need for national regulation. A more significant inquiry is the extent to which a class of small businesses is subject to the abuses which the national law is designed to suppress. ${ }^{72}$ In this connection, it is signifieant that in debating the Taft-Hartley Act, Senator Taft expressed special concern about the abuses existing in the labor relations of small enterprises. ${ }^{73}$ More recently, the McClellan Committee has dramatically documented the genuine basis for such concern. ${ }^{74}$ Under such circumstances, abdication of national power on the ground that each enterprise is small, without regard to the cumulative effect of the relevant abuses, may well involve a perverse surrender of national objectives.

Such surrender will not, moreover, fully achieve the loeal diversity and experimentation which the federalist tradition is designed to promote. The problems of small enterprises are not the same qualitatively as those of larger entities. Thus, to take only one example, a strike in a small enterprise will rarely give rise to a local emergency. Consequently, state competence over small enterprises would not promote the experimentation with arrangements which might improve our not altogether satisfactory methods for dealing with disputes which threaten the welfare of local communities or of the whole country.

71. For example, prior to the Amalgamated decision, Cox urged that the Wisconsin antistrike regulation be validated despite the difficulty of reconciling such a result with the language of the O'Brien case. Cox \& Seidman, supra note 4, at 240-41. After the Amalgamated decision, Cox proposed narrowly drawn legislation which would reinstate state power. Cox, supra note 4, at 1320-21. Furthermore, notwithstanding the fine lines involved, Cox has also proposed a distinction, for pre-emption purposes, between state labor regulation "as such," and general regulation which impinges on labor relations. The problems presented by such a distinction are discussed in text accompanying notes 148-69 infra.

72. Compare the use of such" a standard by the Supreme Court in determining both the extent of the commerce power and of the NLRB's statutory jurisdiction in Polish Nat'1 Alliance v. NLRB, 322 U.S. 643, 648 (1944).

73. 2 LEGIS. Hist. 1005-07.

74. See, e.g., S. REP. No. 1417, 85th Cong., $2 \mathrm{~d}$ Sess. 217-21 (1958). 
These somewhat general observations are reinforced by regard for the character of and the contrast between (a) state regulation bearing on labor relations and (b) the LMRA. State regulation (pre-emption aside) theoretically constitutes a complete system, with the capacity for growth and adaptation inherent in a mixed statutory and common law system. As indicated above, it includes regulation, such as labor relations statutes, tailor-made for labor-management problems. It also includes regulations, such as fair employment practices and safety rules, addressed to the employment relation without regard to whether that relation is subject only to the discipline afforded by the market or to collective bargaining as well. It also includes general tort and contract doctrines and general regulation, such as antitrust and transportation regulation. The application of such general standards to labor relations will in varying degrees reflect the distinctive elements of labormanagement relations.

The substantial problems involved in integrating such a body of regulation with the national scheme will be considered below. ${ }^{75}$ Here it is sufficient to note that uniformity in the regulations controlling labor relations could be achieved only by displacing a vast body of state regulation directed at ends and embodying values not explicitly dealt with in the LMRA or its legislative history. The regulatory vacuum which would result from such a singleminded pursuit of uniformity is so extensive and so incompatible with the federalist tradition as to reinforce the doubts expressed above concerning the desirability of seeking the uniformity which results from an exclusive system of federal regulation.

These doubts are further reinforced by a consideration of the substantive and remedial gaps in the LMRA, which are so serious as to threaten objectives which can fairly be described as basic to the national scheme. The ouster of state power, without regard to whether it advances or retards such objectives, may in concrete situations involve a doctrinaire and perverse application of the supremacy clause.

The federal-state adjustment with respect to stranger and minority picketing is a useful illustration of such perverse results. Until its recent decision in Curtis Bros., ${ }^{76}$ which was reversed by the District of Columbia Circuit, the NLRB's position was that stranger or minority picketing for recognition was not a violation of the LMRA. As a result, an employer subjected to such picketing was faced with a difficult choice: $\mathrm{He}$ could recognize the union, thereby violating the national act; or he could obey the national law and withhold recognition, thereby in many cases risking the strangulation of the enterprise by picketing. Thus, the federal law prescribed certain standards while it

75. See notes $148-69$ infra and accompanying text.

76. Drivers' Local 639, Int'l Bhd. of Teamsters, AFL-CIO (Curtis Bros.), 119 N.L.R.B. 232 (1957), rev'd snb nom. Drivers Union v. NLRB, 2 LAB. REL. REP. (43 L.R.R.M.) 2156 D.C.' Cir. Nov. 26, 1958). 
denied protection against conduct deliberately designed to inflict damage for the purpose of inducing a violation of the governing standards. It is not easy to see the basis for denying to the states the power to avoid so grotesque a result by enjoining the picketing in question. ${ }^{77}$ Such relief would plainly implement a fundamental policy of the national scheme, namely, that the bargaining agent should have uncoerced majority support and that individual employees, absent such support, should be free to bargain for themselves. ${ }^{78}$

It is true that if the states were permitted in the first instance to decide what regulation is a consistent supplement to the federal scheme, error and impairment of the national purpose would be possible. It is also true that correction of such errors by the Supreme Court would normally involve such delays as to be academic with regard to injunctive relief. Nevertheless, where state injunctions restrain protected activity, the power of the NLRB to restrain their enforcement could be developed, thereby expediting curative relief. ${ }^{\text {79 }}$

There is no calculus for weighing the danger of such errors against the difficulties resulting from the destruction of state power to redress the anomalies and gaps in the federal law. But it is at least appropriate to refer to the familiar danger that "uniformity" and "expertise" and "primary jurisdiction" may become shibboleths which divert attention from the question whether state power is deranging or promoting federal purposes. ${ }^{80}$

77. Total pre-emption yields similar results where the employer, faced with conflicting representation claims by rival unions, is picketed for immediate recognition by one of the rivals while the NLRB is processing the rival claims. Although recognition by the employer has been held to be an unfair labor practice, the picketing has not as yet been held to be an unfair labor practice. But cf. Drivers' Local 639, Int'1 Bhd. of Teamsters, AFL-CIO (Curtis Bros.), supra note 76. Under such circumstances some state courts, prior to Garner, would relieve the employer from the conflicting pressures of the LMRA and the picketing by enjoining the picketing. E.g., Goodwins, Inc. v. Hagedorn, 303 N.Y. 300, 101 N.E.2d 697 (1951).

78. For a discussion of the relationship of the premises of the LMRA and minority or stranger recognition picketing, see Meltzer, Recognition-Organtzational Picketing and Right-to-Work Lazes, 9 LAB. L.J. 55 (1958).

79. The Court has denied the jurisdiction of federal district courts to restrain, at the instance of private parties, the enforcement of state injunctions. Amalgamated Clothing Workers v. Richman Bros., 348 U.S. 511 (1955) (5 to 3 decision). But cf. Capital Serv., Inc. v. NLRB, 347 U.S. 501 (1954), which sustained the jurisdiction of the federal district courts to restrain, at the instance of the NLRB, enforcement of state injunctions after the NLRB has issued a complaint covering the conduct subject to state court injunction. In Riclinan Bros., the Court invited efforts by the NLRB to develop methods for barring enforcement of state injunctions against protected activities, stating that "it has not yet been determined that, if an employer resorts to a state court in relation to conduct that is obviously taken over by the Taft-Hartley Act and outside the bounds of state relief, it may not under appropriate circumstances give ground for a finding of an unfair labor practice." Amalgamated Clothing Workers v. Richman Bros., supra, at 520, citing W. T. Carter \& Brother, 90 N.L.R.B. 2020 (1950). In Carter, the Board, with Chairman Herzog dissenting, held that an employer's resort to state court proceedings to enjoin protected conduct was an unfair labor practice. Even the dissenter recognized the Board's paramount authority notwithstanding the state injunction and acquiesced in the Board's order directing the employer to request the state court to vacate the injunction or modify it to conform to the Board's decision.

80. Compare the general approach of Mr. Justice Frankfurter, dissenting in UMW v. Arkansas Oak Flooring Co., 351 U.S. 62, 76 (1956). 


\section{State Competence Over "Violence"}

"Violence," as used in this context, is a comprehensive term encompassing a broad variety of conduct. It includes not only the application of physical force to persons and property but also threats of force explicit or implicit in activities such as mass picketing, and sustained name-calling which may provoke violence. In view of the controversy as to the proper etiquette for the picket line and the wide range of activities connected with picketing, characterization of conduct as "violent" or "peacefnl" may involve both subtle issues of judgment and the risk that the state may lay hands on conduct which the national board might find to be protected.

The Court's validation of state power over violence despite such risks is in sharp contrast to its approach in Garner and Weber. The Court has indicated, without dissent, that state criminal sanctions for violence, incitement to violence, and intimidation are not displaced by the LMRA.81 Similarly, there appears to be full agreement that civil actions, such as personal injury suits, for what may be termed the direct consequences of violence are unaffected by the LMRA.82 The fighting issues have involved the validity of state injunctions against violence and of damage remedies for what can be called the indirect consequences of violence, e.g., loss of profits by an employer or loss of pay by employees resulting from union threats and intimidation which prevented nonstrikers from working. As to these matters, a majority of the Court has recognized state competence, over the persistent dissent of Justices Black and Douglas, who have been joined intermittently by Mr. Chief Justice Warren.

The leading case is United Constr. Workers v. Laburnum Constr. Corp., 83 in which the Court sustained an employer's recovery of compensatory and punitive damages against a umon. The employer, while under contract with an AFL union, had rejected the recognition demand of the defendant union, which had lacked signifieant employee support. Thereupon, the defendant, to secure its demand, had resorted to a campaign of violence and intimidation against the employees involved, thereby forcing the employer to abandon several construction projects. The state award to the employer for the resultant damages rested on the ground that the defendant had tortiously interfered with plaintiff's advantageous relationships. ${ }^{84}$

Although the Court assumed that the defendant had violated subsection 8(b) (1) (A) of the LMRA, it rejected the contention that Garner foreclosed

81. United Constr. Workers v. Laburnum Constr. Corp., 347 U.S. 656, 663-64, 669-70 (1954) ; Allen-Bradley Local 1111, United Elec. Workers v. Wisconsin Employment Relations Bd., 315 U.S. 740,749 (1942).

82. See International Union, UAW v. Russell, 356 U.S. 634, 649 (1958) (Warren, C.J., dissenting).

83. 347 U.S. 656 (1954).

84. 194 Va. 872, 885, 894-95, 75 S.E.2d 694, 703, 709 (1953). 
state action. Its opinion relied principally on three separate, but interrelated, considerations: (1) "Here Congress has neither provided nor suggested any substitute for the traditional state court procedure for collecting damages for injuries caused by tortious conduct." 85 (2) The legislative history plainly showed that federal proscription of violence was not designed to oust state law. ${ }^{86}$ (3) Under common law tort principles, unorganized persons would have been liable for the loss caused by similar violence; the union, which, the Court observed, had lacked any contractual relationship with the plaintiff or its employees, was not immunized against similar liability..$^{87}$

The last ground, together with the Court's supporting citations, ${ }^{88}$ has been read as an acceptance of the view that the pre-emption cases do not oust state laws of general application, as opposed to labor regulation as such, even though such general laws are applied to non-violent conduct involved in a labor dispute. ${ }^{89}$ Before examining that interpretation, it is convenient to consider the post-Laburnum decisions concerning state power over violence.

In UAW v. Wisconsin Employment Relations Bd. (the Kohler case), ${ }^{90}$ the Court upheld an order of the Wisconsin Employment Relations Board restraining violence and mass picketing, even though the order had been based on a state labor relations act and had granted a remedy available under the federal act. The Chief Justice, who had been with the majority in Laburnum, joined Justices Douglas and Black in dissent. The Court explicitly and properly disclaimed any concern with whether Wisconsin had acted through its courts (enforcing a general policy against violence) or through its labor board (enforcing a policy pin-pointed at labor-management relations). The decisive consideration was :

85. 347 U.S. at 663-64. The Court referred to the civil liabilities imposed by $\$ 303$ of the LMRA, but concluded that that provision, instead of impliedly excluding other damage recoveries, made it inconsistent to deny recovery for more flagrant conduct, such as violence. Id. at $665-66$.

86. Id. at 668-69. The Court referred to a statement by the late Senator Taft which approved the duplication of federal and state remedies for violence. This reference has been criticized on the ground that the Court omitted a prior statement by the Senator which reflected the assumption that state law did not reach intimidation which fell short of physical violence. See Bernstein, supra note 4, at 213. Bernstein argues that this assumption, together with the Senator's assumption that there would be federal and state duplication only in "extreme cases," indicates that the Senator was suggesting only that the LMRA might duplicate state criminal law. Although there is some ambiguity in the language relied on by the Court, other portions of the legislative history reflect the understanding of both proponents and opponents of the statute that the states could deal with inass picketing and other threats of violence by means of civil remedies. See, e.g., 2 LEGIS. HIST. 1395-96 (remarks of Senator Taft), 1021.

87. In Laburnum, the Court also urged, in support of state jurisdiction, that private rather than public rights were being vindicated. 347 U.S. at 665 . In Garner, however, this distinction was dismissed as umimportant. 346 U.S. at 492-500.

88. The Court, 347 U.S. at 669 n.11, cited the following: Cox \& Seidman, supra note 4 , at 236; Note, Labor Law-Federal and State Jurisdiction-Common Law Remedies, 27 N.Y.U.L. REv. 468 (1952).

89. See Cox, Federal-State Jurisdiction Over Labor-Managennent Relations, in Wisconsin Industrial Relations Institute, TRENDs in Labor-Management RelaTroNs $139,145-46$ (1956).

90. 351 U.S. 266 (1956). 
The States are the natural guardians of the public against violence. It is the local communities that suffer most from the fear and loss occasioned by coercion and destruction. We would not interpret an act of Congress to leave them powerless to avert such emergencies without compelling directions to that effect.01

In Youngdahl v. Rainfair, Inc., ${ }^{92}$ the Court held that conduct which threatened to develop into, or to provoke, violence was also subject to state injunctive power. In that case, employees struck and picketed to secure recognition of a union as bargaining agent. Although it was not clear whether the union had had majority support, the number of strikers at all times fell short of a majority of the employees. The strike was accompanied by threats against the plant manager and other forms of misconduct, such as the scattering of tacks on the company parking lot and on the driveways of nonstrikers. After about two weeks, the recognition strike and picketing ended. About a month later the strike and picketing resumed as a protest against the employer's denial of recognition to the union and his refusal to reinstate the strikers. In its second phase, the strike was accompanied by some acts of violence and by mounting tension caused in part by sustained and provocative abuse which the strikers directed at the nonstrikers. According to the findings of the Arkansas courts, the strikers' conduct was calculated to provoke violence and was likely to do so unless restrained. Arkansas restrained the strikers and the union representatives from (1) engaging in threats or intimidation directed against nonstrikers, obstruction of the streets, etc., and (2) all picketing. The Court sustained the first phase of the injunction (with the Chief Justice and Justices Black and Douglas dissenting), but invalidated the injunction insofar as it restrained peaceful picketing, as an encroachment on "the pre-empted domain of the National Labor Relations Board." 93

In sustaining Arkansas' power to prevent prospective violence, the Court explicitly and necessarily rejected the contention that the strikers' conduct was protected. ${ }^{94}$ This determination marked the first occasion since BriggsStratton in which the Court overeame its unwillingness to rule in the first instance that conduct was unprotected where NLRA precedents left doubt as to the proper characterization of the conduct. ${ }^{95}$ This approach will prob-

91. Id. at 274-75.

92. 355 U.S. 131 (1957).

93. Id. at 139 .

94. The Court, in rejecting the contention that the concerted activities were protected, cited Chaplinsky v. New Hampshire, 315 U.S. 568, 571-72 (1942), thereby creating some ambiguity as to whether it was concerned with protection of free speech under the fourteenth amendment or the protection conferred by the LMRA. It seems fair, however, to read the opinion as dealing with statutory protection.

95. Under the Board's precedents, the threats and minor vandalism of the strikers were clearly unprotected, but their abusive language, which the Court indicated could be restrained, raised a different question. See NI,RB v. Longview Furniture Co., 206 F.2d 274 (4th Cir. 1953), modifying 100 N.L.R.B. 301, 304 (1952). 
ably be confined to the context of actual or incipient violence. Nevertheless, Rainfair will probably be invoked to support state jurisdiction to enjoin peaceful conduct unprohibited and unprotected by federal law, in accordance with the Briggs-Stratton rationale.

In International Union, UAW v. Russell, ${ }^{96}$ which soon became a cause célebre, the Court recognized state power to grant to individual employees remedies similar to the employer remedies which had been sanctioned by Laburmum. The Court, the Chief Justice and Mr. Justice Douglas dissenting and Mr. Justice Black not participating, sustained an Alabama verdict requiring a union to pay compensatory damages of about 500 dollars (for lost pay) plus 9,500 dollars in punitive damages to a nonstriking employee whose entry into a strike-bound plant had been blocked by mass picketing and threats of violence. The action had been based on the tort of wrongful interference with a lawful occupation.

The Court assumed, arguendo, that subsection 10(c) of the LMRA authorized the NLRB to award lost pay to Russell, notwithstanding Board precedents disclaiming such remedial power. The assumed availability of such compensatory relief, the Court conceded, differentiated Russell from Laburnum, where the Board had lacked the authority to make the employer whole. The Court refused, however, to make this difference decisive, for the following reasons: Congress had not established "a general scheme authorizing the Board to award full compensatory damages for injuries caused by wrongful conduct." ${ }^{\text {"gi }}$ The primary legislative purpose had been "to stop and prevent unfair labor practices"; the Board's power under subsection 10(c) to compensate for lost pay was thus incidental to a scheme of dominantly preventive relief. ${ }^{98}$ Lost pay, even for victims of unfair labor practices, was not a matter of right but depended on the Board's discretion. The overlap of federal and state compensatory remedies did not create the "conflict of remedies referred to in Laburnum." 99 Previous pre-emption cases reflected only a concern that "one forum would enjoin, as illegal, conduct which the other forum would find legal, or that the state courts would restrict the . . rights guaranteed by the Federal Acts." 100

The dissenters urged, first, that under the majority's assumption that compensatory relief was provided by the LMRA, there was a duplication between federal and state remedies, which was inconsistent with the rationale of Garner. The dissenters did not, however, rest on the assumed scope of the Board's remedial authority. They adopted an extremely broad view of federal

96. 356 U.S. 634 (1958).

97. Id. at 643 .

98. Id. at 642-43.

99. Id. at 644 .

100. Ibid. 
pre-emption, which would deny the states the power to grant damages for the indirect economic consequences of violence even though the NLRB also lacked such power. Their argument proceeded as follows: "The Federal Act represents an attempt to balance the competing interests of employee, union and management. By providing additional remedies the States may upset that balance as effectively as by frustrating or duplicating existing ones."101 Such remedies, varying especially in their punitive aspects from state to state, would destroy the uniform scheme of national regulation, which the LMRA was designed to achieve. The threat of varying damages was also inconsistent with the statutory objective of promoting industrial peace. The prospect of lucrative punitive relief would deter recourse to the "curative" federal machinery, and private litigation would, as the dissent in Laburmum had emphasized, drag on, "keeping old wounds open."102 This langnage can scarcely be reconciled with the result or the reasoning in Laburmum, a decision in which the Chief Justice, who now spoke for the dissenters, had joined.

The dissenters, sensitive to the difficulties posed by Laburnum and unwilling to distinguish it by conceding the Board's authority to award lost pay, pointed to three other grounds of distinction: (1) Since an employee's abstention from concerted activities is protected by Section 7 of the LMRA, the union's interference with the nonstriking employee in Russell directly and inherently involved a violation of subsection $8(\mathrm{~b})(1)(A)$, whereas that subsection had been involved only "fortuitously" in the union's interference with the employer's interest in Laburnum. (2) Since the defendant union in Russell had been the certified bargaining representative, its conduct was an incident of an ordinary economic dispute which would, presumably, be followed by continuing labor-management relations. In Laburnum, per contra, the defendant union had been a stranger attempting to displace an incumbent union by "predatory" coercion of both the employees and the employer. There was, accordingly, no prospect of continuing relations between the litigants and no need to consider the possibility that litigation might prejudice such relations. (3) Finally, in Laburnum, only one plaintiff, the employer, could recover punitive damages; whereas all of the many employees affected by the conduct in Russell could successively recover punitive damages, a prospect aggravated by the Alabama rule that evidence of a previous punitive recovery was inadmissible in a subsequent action.

There are obvious difficulties in reconciling the position of either the majority or the dissent with the Court's precedents. Furthermore, comment on the separate opinions is complicated by the fact that they proceeded on different assumptions regarding the NLRB's remedial authority. As for the majority opinion, the distingnishing of Garner and related cases solely on the

101. Id. at 650 (dissenting opinion).

102. Id. at 654 (dissenting opinion). 
ground that they involved preventive, rather than damage, relief is questionable. As Judge Traynor has urged with characteristic insight, state damage actions, like injunctions, enforce policy and control conduct albeit somewhat more indirectly. ${ }^{103}$ In addition, they involve the possibility of the same kinds of conflict which the broad language of Garner apparently was designed to suppress. ${ }^{104}$ Thus, states purporting to apply substantive standards identical to those embodied in the federal scheme inay because of diverse attitudes and procedures reach different results in particular cases. Moreover, state dainage remedies may be imposed for conduct which might be held protected under the federal scheme, and the possibility of such awards would operate to restrain activities which the LMRA, as previously interpreted by the Court, was said to free from all restraints. If an adequate compensatory remedy is supplied by the federal act, it is not easy to see any special justification for running the risks of state adjudications which would overlap or conflict with the federal scheme.

Nor is any convincing argument for such state action (given the premises of Garner) supplied by the Court's attempt to minimize the importance of the compensatory remedy which it assumed was provided by the LMRA. Even though damage remedies under the LMRA are "incidental" to a scheme of dominantly preventive relief and even though they are entrusted to the Board's discretion, these considerations do not affect the impact of the Board's compensatory powers on conduct or the potentiality of conflict between state and federal action. Indeed, in many situations it is the fear of back pay liability which is the decisive deterrent to unfair labor practices since the NLRB's purely preventive processes give wrongdoers one free bite.

In view of the presence of violence in Russell, the Court's broad distinction between damage and injunctive relief was plainly not necessary for the decision. Violence and related conduct, as Garner ${ }^{105}$ and other cases suggest, ${ }^{106}$ present a special case. The paramount responsibility of the states for dealing with violence, the importance of recognizing power adequate to responsibility, and the pertinent legislative history ${ }^{107}$ appear to justify the recognition of state power over actual or incipient violence despite a potential overlap or conflict between state and federal regulation.

The Court in Russell did not, however, make it clear that violence is a special case. Its narrow reading of previous pre-emption cases may be interpreted as a general authorization of state damage actions without regard to

103. Garmon v. San Diego Bldg. Trades Council, 49 Cal. 2d 595, 619-20, 320 P.2d 473, 488 (Traynor, J., dissenting), cert. granted, 357 U.S. 925 (1958).

104. See id. at 618,320 P.2d at 487 (dissenting opinion).

105. See 346 U.S. at 488 .

106. See San Diego Bldg. Trades Council v. Garnion, 353 U.S. 26, 29 (1957) ; United Constr. Workers v. Laburnum Constr. Corp., 347 U.S. 656, 667-68 (1954).

107. See note 86 supra and accompanying text. 
whether violence is involved or whether such actions are necessary to fill remedial gaps in the federal scheme. Such state power would naturally be limited so as to exclude encroachment on protected activities. It should be observed, however, that the opinion, by stressing the "kind of conduct . . . involved,"108 suggests that the departure from Garner may well be confined to situations involving violence.

The extent to which Garner should be limited in actions for damages, as opposed to injunctive relief, can more conveniently be explored below. At this point, it is sufficient to note that the special history and characteristics of the injunction in labor disputes might serve to justify a distinction, for preemption purposes, between damage and injunction cases. Labor's hostility to the labor injunction resulted in part from the fact that the consequences of an erroneous injunction often could not be reversed by a successful appeal because changes in the circumstances underlying the dispute precluded resumption of strikes or picketing. A reversal of erroneous damage awards could, however, come closer to restoring the status quo.

As for the dissenting opinion in Russell, its major premise that any additional state remedy would destroy the balance in labor relations which Congress sought to create involves a somewhat cavalier treatment of both the legislative purpose imputed to Congress by Laburnum and the underlying questions of policy. Congress, according to Laburnum, had been unwilling to oust state remedies for violence and had not in that connection suggested a distinction between state damage remedies for violence, as such, and those for its economic consequences. There are, moreover, strong considerations against such fragmentation of state competence-considerations which are particularly forceful if, as the dissenters apparently assumed, the federal scheme does not provide for compensatory relief in the Russell situation. The primary responsibility of states for dealing with violence is a familiar aspect of our federalist tradition. For this purpose, "civil responsibilty and public punishment by common usage have long been established as appropriate and complementary associates." 100 I11deed, in labor disputes, civil liability is on occasion a more effective deterrent than the criminal law. Prosecutors may be reluctant to take action becatuse of inertia, sympathy with the strikers, or political indebtedness to the interests involved. Juries may be unwilling to convict individuals whose wrongdoing occurred in the surcharged atmosphere of a labor controversy, but may be willing to grant compensatory relief against an impersonal association. Such

108. 356 U.S. at 642. A narrow area for state competence over tort actions is also suggested by the summary of Laburmum contained in both International Ass'n of Machinists v. Gonzales, 356 U.S. 617, 621 (1958), and the $W e b e r$ case, 348 U.S. at 477.

109. Abounader v. Strohmeyer \& Arpe Co., 243 N.Y. 458, 465, 154 N.E. 309, 311 (1926). See generally Jaffe, The Public Right Dogma in Labor Board Cases, 50 Harv. L. Rev. 720, 734-37 (1946) ; Thayer, Public Wrong and Privale Action, 27 HARV. L. REV. 317 (1914). 
reluctance may be especially strong when violence has not actually erupted into physical attack but, as in the case of mass picketing and related techniques, is implicit in the total situation. An assumption of a "federal balance," which gains no support from either the legislative history or the general traditions of federalism, scarely justifies the denial of state power to employ civil actions as a device for deterring violence and compensating its victims.

The dissenters' argument, pushed to the limits of its logic, would not merely fragment state power over violence in labor disputes but would destroy it completely. State criminal statutes, if they are enforced, involve dangers similar to those implicit in civil remedies. They bring diverse local attitudes and procedures to bear on conduct occurring in the context of labor controversies. They also involve the risk that activities which might be protected under the national scheme might be made "too risky to undertake." Furthermore, the institution and prosecution of criminal actions may also poison a continuing relationship. In short, the considerations urged by the dissenters to support the ouster of state civil remedies-notwithstanding the remedial deficiencies of the federal scheme-equally support the ouster of state criminal sanctions.

The basic difficulties with the dissent arise, in my opinion, from a onesidedness in striking a balance between the interests at stake. The dissenters appeared to be so preoccupied with a contingent and remote limitation on the union's protected activities that they neglected the actual and direct interference with Russell's protected activities. Presumably, it was this one-sided emphasis which led the dissenters to urge in effect that measurable economic loss deliberately inflicted by violence and intimidation in violation of both federal and state laws should currently not be compensable under either system. Such a self-defeating jurisprudence, which might be read as an encouragement to violence in the context of labor-management relations, would scarcely promote the search for orderly adjustments in that context or in other contexts where law is challenged by force.

A similar preoccupation with a single interest underlies the dissenters' fears that state remedies for violence would disturb a continuing labormanagement relationship. The fostering of a proper climate for such relationships is, of course, an important objective of labor policy. But it is a familiar point that employees and employers as well as unions are parties to that relationship. Disregard of, or inadequate remedies for, union violence against employees or employers may in some situations appear to avoid strains on the tripartite relationship. But in other situations violent conduct which might have been checked by appropriate deterrents may generate such strains.

Whatever the uses and dangers of appeasement in this context, both federal and state law have proscribed violence. The federal act implies, moreover, that the risks of disturbing continuing relationships are a justifiable 
cost of avoiding abuses by the interests involved. Thus any charge that an incumbent union has violated the LMRA may disturb such a relationship. Furthermore, section 301 of the LMRA provides for liability for breach of collective bargaining agreements, and section 303 , for violations of the restrictions imposed on unions by the provisions of subsection $8(\mathrm{~b})(4)$ of the act. The enforcement of such liabilities is not without risks to continuing relationships. The dissenting opinion does not make it clear why similar risks should become intolerable where liability for the economic consequences of violence is involved.

The dissenters' specific grounds for distinguishing Russell from Laburmum are no more convincing than their general approach to federal-state power over acts of violence. First, even if the protection against violence afforded to an employee by subsection 8(b)(1)(A) is "direct" and the employer's protection "derivative," these labels do not suggest that an employee should be deprived of adequate compensatory relief. Indeed, the contrary conclusion seems more acceptable. Congressional preoccupation with the employees' rights scarcely warrants the destruction of their compensatory remedies while "compensatory relief" for employers is preserved. Secondly, the fact that the defendant union in Russell was certified whereas the defendant in Laburmum was a stranger attempting to displace the incumbent, although it plainly made the conduct in Laburnum more distasteful, scarcely serves as a basis for a legal distinction. Neither Laburnum nor the LMRA suggests that that fact should destroy all compensatory relief for violence elearly prohibited by federal as well as state law. ${ }^{110}$

The final difference between Russell and Laburnum urged by the dissenters, the prospect of multiple punitive damage awards in Russell, is an appealing basis for distinguishing the cases. But it is difficult to convert that difference into an acceptable basis for a legal distinction, however desirable it may be as a matter of policy to exclude punitive damages from this area. If, as Laburnum indicated, state compensatory and punitive remedies for violence and its consequences are valid, one of the familiar risks of recognizing state power under a federalist scheme is that it will be exercised harshly or unwisely. But neither the pre-emption cases nor the commerce clause provides

110. It should be observed that the arrangements with the incumbent union in the Laburmum case provided for exclusive hiring of skilled workers through AFL unions and for the unions' consent to the hiring of unorganized unskilled workers. 347 U.S. at 660 n.4. The arrangement, which appeared to contemplate either a closed shop or the preferential hiring of unionized workers, was illegal under the LMRA. This considerstion should not affect the validity of the result in Laburmum since violent self-help to remedy violations is scarcely justifiable in view of the orderly remedies afforded by the LMRA. But cf. Bernstein, supra note 4, at 211-12. Nevertheless, the probable illegality of the arrangements between the incumbent unions and the employer in Laburntum is an additional reason for questioning the force attaclied by the dissenters to the fact that an incumbent union as well as the employer was the object of the rival union's violence in Laburmum. 
the yardsticks for measuring the validity of successive penalties for conduct which may, but need not, be considered a single transaction. The due process clause of the fourteenth amendment would appear to be more relevant. Furthermore, similar risks of multiple punitive sanctions exist where an employee brings an action for personal injuries inflicted by violence during a labor dispute or for the fear caused by the threat of such violence, or where the state charges a union or its officers with multiple criminal offenses. The dissenters, as already indicated, appeared to concede state competence over such actions, ${ }^{111}$ including, presuniably, competence to grant successive punitive damage awards. Such damage awards, despite differences in the underlying legal concepts, would have substantially the same impact on labor-management relations as the award in Russell. It is, accordingly, extremely difficult to articulate a coherent concept of pre-emption which would warrant the distinction drawn by the dissent between the two types of awards. ${ }^{112}$

111. See note 82 supra and accompanying text.

112. The overlapping state and federal jurisdiction recognized in Russell may give rise to troublesome questions as to the effect in an NLRB proceeding of a prior state judgment and the effect in a state proceeding of a prior NLRB determination. This footnote, which is not based on a comprehensive examination of the authorities, is designed only to raise such questions.

A state determination that a union's conduct was violent would not appear to be binding in a subsequent Board proceeding arising from a charge that the employer had violated the LMRA by disciplining employees who had participated in the assertedly non-violent activities. Under familiar doctrines concerning collateral estoppel, the General Counsel of the NLRB, not having been a party to, or in control of, the state litigation, would not be bound by the state judgment, quite apart from questions which might exist concerning the identity of issues. Cf. New York State Labor Relations Bd. v. Holland Laundry, 294 N.Y. 480, 489-95, 63 N.E.2d 68, 72-75 (1945). Furthermore, collateral estoppel of the NLRB would appear to be precluded by LMRA $\$ 10$ (a), which states that the Board's powers shall not be affected by any other means of adjustment. Cf. Lyons v. Westinghouse Elec. Corp., $222 \mathrm{~F} .2 \mathrm{~d} 184$ (2d Cir.) (L. Hand, J.), cert. denied, 350 U.S. 825 (1955), 55 Corum. L. REv. 1078. But cf. Vanderveer v. Erie Malleable Iron Co., 238 F.2d 510 (3d Cir. 1956).

Nevertheless, Judge Magruder has suggested, without deciding, that "a holding that the Board is bound by the findings in the state injunction proceeding might perhaps be justified" in that it might "facilitate the reestablishment of labor stability in the disrupted plant." NLRB v. Thayer Co., 213 F.2d 748, 754 (1st Cir. 1954). Despite the force of Judge Magruder's comments, the provisions of $\$ 10$ (a) and the importance attached by the Supreme Court to uniform and centralized administration of the LMRA make it unlikely that conventional requirements of collateral estoppel would be relaxed so as to give binding effect in ań NLRB proceeding to prior state determinations which are invoked against the Board.

More troublesome is the problem presented by the converse situation, i.e., whether an explicit or implicit Board determination that conduct is protected is binding in a state proceeding arising out of a claim that the conduct in question was violent, tunprotected, and therefore within the state's jurisdiction. Even though the party asserting the state claim had been the complainant before the Board, the fact that control of Board proceedings is vested in the General Counsel would appear to negate the "privity" generally required for collateral estoppel. Nevertheless, in the light of Garner, it would be strange to permit a state to award damages for conduct previously characterized as protected by the Board. Garner pre-empted state jurisdiction in part to avoid the possibility of state interference with activities which might be found by the Board to be protected. To sanction state action against conduct previously characterized as protected by the Board would thus appear to be incompatible with the purposes behind Garner and other preemption cases. But due process considerations, as well as orthodox collateral estoppel requirements, would present serious obstacles to a holding that a party to a state proceeding is bound by a previous characterization of conduct in a national proceeding to which 
State competence over violence and "trespass" are related because of the impact of property violations on public order. In Fairlazen, ${ }^{113}$ the Court expressly reserved the trespass question. But decisions involving unfair labor practices make it plain that "property rights" are limited by the need to protect the employees' statutory rights. ${ }^{114}$ There will doubtlessly be a similar accommodation in equitable and legal actions for trespass. Such actions will raise a troublesome issue, viz., the extent to which the Court will relax its fluctuating and unrealizable requirement of primary interpretation by the Board. The connection between trespass and violence suggests that the Court's disregard of this requirement in the violence eases may carry over into the trespass situation. But an important consideration against such a result consists of the greater difficulties involved in accommodating property "rights" with the "rights" protected by section 7. These difficulties may impel the Court to protect the Board's primary interpretation at the expense of another traditional area of state responsibility. Here, as in other contexts, the issue is whether the theoretical possibility of conflict should result in the regulatory and remedial vacuum which would follow the displacement of state power. Supplementing the general considerations already urged against such a result is the point that employees whose statutory rights are invaded may secure relief through the Board, ${ }^{115}$ whereas employers whose property rights are invaded would be deprived of any preventive relief by pre-emption.

he was not a party. Such obstacles might be avoided, however, on the ground that the national government, which could completely oust state jurisdiction, can so condition its exercise as to avoid encroachment on activities determined by the NLRB to be protected. Such an approach would in turn invite the contention that an unconstitutional condition was being imposed on state jurisdiction. Prediction in this situation is obviously hazardous. But national characterization of conduct may well be held controlling in a subsequent state proceeding in order to implement the purposes implicit in the pre-emption decisions. In any event, the exercise of state jurisdiction in such situations will, of course, be subject to review by the Supreme Court if it is urged that the state action encroaches on protected activities.

Interesting complications also arise where a prior Board or state determination is offered against a party to the earlier proceeding. For example, a finding by the Board that a union, defendant in a Board proceeding, was guilty of violence may be offered against that union when it is defending a state action for damages. The absence of mutuality would not in some jurisdictions preclude a holding that the defendant in the state action is bound by the prior Board determination. See Currie, Muttuality of Collateral Estoppcl: Limits of the Bernhard Doctrine, 9 STAN. L. REv. 281 (1957). Nevertheless, a state might reject such a result on the ground that it would be incompatible with its "exclusive jurisdiction" over the cause of action involved. Cf. Lyons v. Westinghouse Corp., stipra. Federal jurisdiction in diversity actions over such state-created rights could be reconciled with the claims of the states' "exclusive jurisdiction" on the ground that a federal court, under the Erie doctrine, is an arm of state law.

In the converse situation, the Board would appear to be prevented by $\S 10$ (a) from binding a defendant in a Board proceeding by a finding against him as a defendant in an carlier state proceeding.

113. Amalgamated Meat Cutters, AFL v. Fairlawn Meats, Inc., 353 U.S. 20, 24-25 (1957) ; cf. Allen-Bradley Local No. 1111, United Elec. Workers v. Wisconsin Employment Relations Bd., 315 U.S. 740, 744, 749 (1942) (upholding Wisconsin order which restrained not only mass picketing and intimidation, but also picketing of employees' homes).

114. See NLRB v. Babcock \& Wilcox Co., 351 U.S. 105 (1956).

115. See ibid; Capital Serv., Inc., v. NLRB, 347 U.S. 501 (1954). 


\section{State Damages for Non-Violent Conduct}

The uncertainties flowing from Garner and Weber, which divided the Court in Russell and Gonzales, also complicate state competence over damage actions for non-violent conduct. The difficulties involved are suggested by the Garmon litigation in California. In Garmon, the Supreme Court expressly reserved the question of state competence to grant damages for peaceful picketing for recognition and a union shop, by a union which lacked majority support.116 After remand, the California Supreme Court, in a four to three decision, sustained the damage award, relying principally on the Laburnum decision. ${ }^{117}$ Judge Traynor, in dissent, properly urged that Garmon, because it did not involve violence, was critically different from Laburnum. Reading Laburnum against the background of Garner, he concluded that California had been ousted of jurisdiction.

There is a strong basis for Judge Traynor's argument. If the picketing for some or all of the purposes involved is not a federal violation, the state damage award impairs the national policy by restraining conduct "designed to be free" of any obstruction. If, per contra, the picketing is federally prohibited, the state grant of a damage remedy not provided by the national scheme would derange it far more than the parallel remedy which was invalidated in Garner. Furthermore, state characterization of the conduct prior to NLRB action runs counter to the NLRB's duty of "primary interpretation and application" which was accorded such great importance in Garner. A requirement of primary interpretation in the circumstances of Garmon is, of course, particularly bizarre given the Board's refusal, because of selfimposed jurisdictional limitations, to process the employer's charge. But this anomaly is a general consequence of Guss rather than of the denial of state competence to grant damages.

Although the general argument outlined above has not only Judge Traynor's impressive support but also that of able commentators, ${ }^{118}$ it involves substantial difficulties. The first set of difficulties arises from the fact that the minority-recognition picketing was coupled with a demand for a union shop. As a consequence, the picketing constituted not only a violation by the union of Subsection $8(\mathrm{~b})(2)$ of the LMRA but also an attempt by it to force the employer into a violation of subsection 8 (a) (2). But more important, the demand for a union shop requires consideration of the implications of Subsection 14(b) of the LMRA and its legislative history.

116. San Diego Bldg. Trades Council v. Garmon, 353 U.S. 26, 29 (1957).

117. Garmon v. San Diego Bldg. Trades Council, 49 Cal. 2d 595, 603, 320 P.2d 473, 478, cert. granted, 357 U.S. 925 (1958).

118. See Cox, Labor Decisions of the Supreme Court at the October Term, 1957, 44 VA. L. Rev. 1057, 1065-74 (1958) ; Hays, State Courts and Federal Preemption, 23 Mo. L. Rev. 373, 396-97 (1958). 
There is a strong argument, elaborated below, ${ }^{110}$ that the state authority sanctioned by that subsection should extend not only to consummated union shop arrangements illegal under a state law but also to antecedent pressures designed to achieve such arrangements. If this argument is granted, Garmon raises the question whether such antecedent pressures should be subject to state authority even though a state, instead of broadly condemning union shops and pressures to achieve them, lays down a narrower prohibition applicable to picketing for a union shop only where the union lacks a majority.

There is nothing in the LMRA or in a coherent concept of federalism which would warrant a recognition of state competence to enforce the broader prohibition, but a demal of competence to enforce the narrower one..$^{120}$ Such a distinction would, indeed, grotesquely pervert the principle of majority support embodied generally in the LMRA and particularly in its regulation of union security arrangements.

Reliance on Garner to deny state jurisdiction in Garmon raised a second and a more important set of difficulties, which would exist even in a case not involving a demand for a union shop clause. It is appropriate, because of the uncertain status of the Board's Curtis decision, to examine these difficulties on alternative assumptions as to the ultimate fate of the Board's doctrine that picketing for recognition in the absence of majority support violates the LMRA.

If the Supreme Court approves that doctrine, state competence in situations such as Garner should, I believe, be sustained. Stranger or minority picketing for recognition is, as indicated above, incompatible with the basic objectives and provisions of the national law. Although the LMRA would proscribe such conduct, it would not afford employers a compensatory remedy for the economic losses which are the object and the result of the union's conduct. Consequently, only the states can now provide adequate compensation for the deliberate infliction of economic loss by conduct which violates both state and federal law. Furthermore, the delay surrounding preventive relief through the processes of the national board increases the need for civil liability as an adjunct to the Board's preventive relief. These considerations make the case for state competence in the Garmon situation even stronger than in the Russell situation where the Court assumed that the

119. See notes $125-47$ infra and accompanying text.

120. The California court did not clearly indicate that the union shop demand entered into its proscription of the picketing. The union's objective was held illegal under California law because it would "require the plaintiffs to interfere with the bargaining rights of their employees and force upon them ternis and conditions of their employment and labor representation not of their own choosing and which in fact they had rejected." $49 \mathrm{Cal} .2 \mathrm{~d}$ at 607,320 P.2d at 480 . Despite California's failure to pin-point the significance of the union shop demand, its existence could properly be considered in a Supreme Court ruling on state power. This is especially appropriate because the failure of California to emphasize that deniand is attributable to the Supreme Court's precedents concerning $\S 14(\mathrm{~b})$, which, it is suggested below, ignore the purpose and history of that section. 
federal law provided adequate money damages and where the complication of multiple claims for punitive damages existed.

Judge Traynor has, however, properly urged that permitting state damage awards in the absence of violence involves a greater danger of erroneous decisions by state courts attempting to distinguish between prohibited and protected conduct. ${ }^{121}$ Several persuasive reasons suggest, however, that this consideration does not warrant the destruction of state competence to grant damages for non-violent but federally prohibited activities where such competence is necessary for an adequate compensatory scheme. First, there is a similar danger in the violence context, namely, that of disparate federal and state findings and characterization of facts as well as disparate approaches to elusive issues of vicarious responsibility. A more important consideration is the implication of Section 303 of the LMRA that Congress was prepared to tolerate such differences where they are the price of an adequate compensatory scheme. Section 303 expressly authorizes state and federal courts to award damages for violations of subsection $8(\mathrm{~b})(4)$ of the act. ${ }^{122}$ The jurisdiction of the courts is, moreover, independent of the Board's. As a result, the same conduct may be held to be unprohibited, and impliedly protected, by the Board and yet may be the basis of a damage award in the court action. ${ }^{123}$ It is true that to the extent that such conficts result from different interpretations of the federal statute, state application of section 303 could be harmonized with federal adjudications by the exercise of the Supreme Court's reviewing power. But the Court could not reach conflicts resulting from reasonable differences in fact determination, and provisions such as section 303 which turn on "purpose" are, of course, a fruitful source of such conflicts. Furthermore, the Supreme Court could exercise its reviewing authority to strike down damage awards based on state law if such awards encroach on federally protected activities. Such review would inescapably involve the possibilities of federal and state conflict, but, like the conflict arising from section 303 , which is not fundamentally different, it

121. Garmon v. San Diego Bldg. Trades Council, 49 Cal. 2d 595, 615, 618-19, 320 P.2d 473, 485, 487-88 (1958).

122. The express provision for jurisdiction in $\$ 303$ invites the inclusio unius argument. But that argument is far from persuasive. That section's provision for judicial remedies reflected the strong congressional disapproval of the secondary and other pressures proscribed in $\S 8$ (b) (4) of the LMRA. The explicit provision in LMRA for state and federal competence over damage actions for conduct deemed particularly obnoxious by the Congress indicates only that damages were to be granted for such conduct despite varying state rules as to the legality of such conduct. It does not indicate that all other state damage remedies for non-violent conduct were to be ousted regardless of the impact of the conduct on the federal purposes and the remedial gaps in the federal scheme. Plainly, both Laburnum and Russell reject any mechanical inclusio unines argument based on $\$ 303$.

123. See International Longshoremen's Union v. Juneau Spruce Corp., 342 U.S. 237 (1952); United Brick Workers v. Deena Artware, Inc., 198 F.2d 637 (6th Cir.), cert. denied, 344 U.S. 897 (1952). 
should be dismissed as the price for adequate remedies against conduct banned by both state and federal law.

The alternative assumption concerning Curtis, viz., that minority picketing for recognition will be lawful under the LMRA, would make the recognition of state competence in the Garmon situation considerably more troublesome. The states would then be awarding damages for activities which are neither prohibited nor protected. In this context, there is morc force to the claim that state additions to the substantive, as opposed to the remedial, law of labor relations would derange the balance struck by the federal act. If, in accordance with Garner, the interest in centralized and uniform interpretation precludes the states from granting parallel remedies for activity apparently prohibited by federal law, it would appear, a fortiori, that the states are barred from applying additional substantive standards and thereby limiting conduct ungoverned by the national act. But before that plausible argument can be accepted, the reasons for denying group activities the protection of the statute must be considercd. Such protection is in general denied because the conduct involved is deemed incompatible with the objectives of the LMRA, or of some other federal statute, or with notions of the mutual responsibilities of employer and employee, or because the unprotected conduct invades an employer interest considered paramount. The fact that such marginal activities are denied the statutory protection may be read either as a declaration of national neutrality with respect to supplementary state power or as a declaration that the states also should abstain from regulation.

The general problems underlying the choice involved may be illustrated by reference to a concrete situation. A union may picket or exert other pressures to obtain recognition despite the fact that a rival union also is claiming majority status and the Board is processing the representation question. If an employer grants recognition because of the picketing, he violates the LMRA. If, in obedience to the national law, he withholds recognition, he runs the risk of substantial losses as a result of the union's pressures. The national board, pending the election, presumably cannot move to enjoin the picketing ; ${ }^{124}$ in any event, its processes may be too slow to grant effective protection. State injunctive power is at least subject to the uncertainties flowing from Garncr, and is probably foreclosed. If employees participated in the picketing, the employer would, of course, have the theoretical right to discharge them. But that right may be a paper right either because the employer cannot secure employees with requisite skills or because discharge would aggravate a tense situation.

124. The reasoning of Drivers Local 639, Int'1 Bhd. of Teamsters, AFL-CIO (Curtis Bros.), 119 N.L.R.B. 232 (1957), rev'd sib nom. Drivers Union v. NLRB, 2 LAB. REL. REP. (43 L.R.R.M.) 2156 (D.C. Cir. Nov. 26, 1958, might be extended to deal with this situation. 
Under the foregoing circumstances, the recognition of state competence to grant damages would serve substantially the purpose which lies behind the characterization of the employee's activities as unprotected, i.e., it would to some extent deter such conduct. State damage awards would, moreover, be implementing a central purpose of the national scheme by protecting the integrity of the Board's representation machinery as well as the principle of majority rule.

It is true that the foregoing considerations could also be urged to support state injunctive relief in the situation described above. Nevertheless, Russell, albeit in a context of violence, drew a distinction between damages and injunctive relief; a distinction which is supported by the fact that damage awards encroaching on protected activities are more amenable to effective correction than erroneous injunctions. Furthermore, Laburmum emphasized the absence of "conflict" between the state remedy and federal administrative relief. These considerations suggest the slim possibility that the battered principle of BriggsStratton may be revived in the context of actions for damages.

\section{Union Security Provisions, Internal Union Affairs, and Related Matters}

The Wagner Act did not affirmatively sanction or prohibit the closed shop or other forms of union security arrangements. Although the act was silent as to state authority, its legislative history indicated that the states were to retain authority to prolibit or regulate such arrangements. ${ }^{125}$ Subsection 14 (b) of the Taft-Hartley Act expressly empowers the states to prohibit union security arrangements which, in the absence of state regulation, would be permitted by section 8 of the statute. ${ }^{126}$ The legislative history of subsection 14(b) suggests that its purpose was not merely to sanction state regulations more restrictive than the federal prohibitions, but rather to preserve concurrent state regnlation without regard to whether it supplemented or overlapped the federal scheme. ${ }^{127}$ In other words, the legislative history indicates that subsection 14 (b) was designed to preserve for the states the same power to deal

125. Relevant extracts are set forth in Algoma Plywood \& Veneer Co. v. Wisconsin Employment Relations Bd., 336 U.S. 301, 307-10 (1949).

126. Subsection 14(b) might be read as bringing into play the federal prohibition against discrimination embodied in $\$ \S 8(a)(3)$ and $8(b)(2)$ of the LMRA when union shop arrangements violate state law. But the proviso to $\$ 8(a)(3)$ interposes technical obstacles to such an interpretation. It provides that "nothing in this Act or in any other statute of the United States, shall preclude an employer from making" union security agreements which conform to the requirements imposed by Taft-Hartley. Furthermore, the legislative history of \&14(b) suggests that it was not designed to incorporate state law into the LMRA, but only to authorize state invalidation of union security agreements permitted by the LMRA.

127. H.R. 3020, 80th Cong., 1st Sess. (1947), which, after amendments, became the LMRA, provided in $\S 13$ that union security arrangements were "divested of their character as a subject of regulation by Congress under its power to regulate commerce ... to the extent that such agreements shall, in addition to being subject to any applieable 
with union security arrangements which they had under the Wagner Act. ${ }^{128}$

The Court has not, however, explicitly recognized the unique problems posed by subsection 14 (b) and the pertinent legislative history. Its early treatment of state power in this area proceeded on the assumption which underlay Garner, namely, that overlap between federal and state remedies was fatal to state competence. Thus, as indieated above, ${ }^{120}$ Plankinton, a per curiam decision, denied state authority to grant affirmative relief fron union security arrangements violating state law where such relief duplicated remedies available under the LMRA. Furthermore, the Court's later explanation of Plankinton implied that the states were barred from granting relief of any kind for conduct discriminating against nonunion (or union) employees if such conduct constituted a federal unfair labor practice. ${ }^{130}$

The recent Gonzales case ${ }^{131}$ introduced new uncertainties concerning state action which involves such a partial or complete remedial overlap. In Gonzales, the Court, divided as in Russell, affirmed a California decision restoring the plaintiff to union membership from which he had been expelled and awarding him damages for lost pay and for physical and mental suffering. In the California litigation, the plaintiff had relied on the doctrine that a union constitu-

provisions of this Act, be subject to the operation and effect of such state laws and constitutional provisions as well." 1 LegIS. HIST. 80-81. See also H.R. REP. No. 245, 80th Cong., 1st Sess. 34, 44 (1947), 1 LEgrs. HISr. 325, 335. The final version of $\$ 14$ (b) was agreed to in the course of conference to reconcile the House bill with the Senate bill which did not contain a corresponding provision. The House conference report stated: "It was never the intention of the National Labor Relations Act ... . to preempt the field ... so as to deprive the States of their powers to prevent compulsory unionism. .. . To make certain that there should be no question about this, section 13 was included in the House bill. The conference agreement, in Section $14(\mathrm{~b})$, contains a provision having the same effect." H.R. Rep. No. 510, 80th Cong., 1st Sess. 60 (1947), 1 LEGIS. HIsT. 564. Subsequently, in the debates, Senator Ball referred to the provisions embodied in $\$ 14$ (b) as "new" and to "the compromise in the House on language spelling it out." 2 LEGIS. HIst. 1546. Senator Taft replied: "The Senate committee report stated on its face that State laws would still remain in effect. All we have done is to write in expressly what our committee report said." Ibid. No statement in the Senate committee report, S. ReP. No. 105, 80th Cong., 1st Sess. (1947), 1 LEg1s. HIST. 407-504, has been found which has the tenor suggested by Senator Taft. See id. at 6, 1 LeGis. HIST. 412-13, which Senator Taft apparently had in mind. See also 2 LEGIS. HIST. 1596-97. Nevertheless, his statement on the floor is wholly consistent with concurrent state power, and the statement in the Senate committee report is not inconsistent with such power.

128. Senator Taft stated that the LMRA did not "in any way prohibit the enforcencnt of State laws which already prohibited closed shops." 2 LEGIS. HIsT. 1597. Altlough "closed shops" are technically distinguishable from Taft-Hartley union shops, the legislative history, summarized above, suggests that the quoted phrase was not being used as a word of art.

My own views on the proper interpretation of $\$ 14$ (b) are not unconsciously shaped by any liking for "right-to-work" laws, which $I$ have criticized elsewhere. Meltzer, supra note 78 , at 62 .

129. See text accompanying note 44 supra.

130. See text accompanying note 45 supra. It should be noted, however, that the Court, relying on the legislative history to justify its departure from the literal language of $\$ 14$ (b), has sanctioned state regulations which, instcad of prohibiting union security arrangements, imposed requirements supplementing those imposed by the LMRA. See Algoma Plywood \& Veneer Co. v. Wisconsin Employment Relations Bd., 336 U.S. 301, 314 (1949). The NLRB, in at least one case, appears, however, to have neglected the implications of this decision. Cyclone Sales, Inc., 115 N.L.R.B. 431 (1956).

131. International Ass'n of Machinists v. Gonzales, 356 U.S. 617 (1958). 
tion constitutes a "contract"132 between the union and its membership and had urged that under state law he was entitled to both restoration of membership and damages as a remedy for the union's breach of that contract through wrongful expulsion. The Court, by Mr. Justice Frankfurter, confirmed state power over membership rights-a point conceded by the dissenters and the defendant. Turning to the disputed issue-state power to grant damages for loss of employment resulting from the plaintiff's expulsion-the Court, in sustaining state competence, emphasized three grounds: (1) the crux of the California action was breach of contract; (2) it was desirable to afford the plaintiff a complete remedy for the invasion of his rights; and (3) the facts raised "doubts" (which the dissenters properly considered exaggerated) as to the availability of a federal remedy for the lost pay. ${ }^{133}$

The dissenters reiterated the principal points of the Russell dissent: erosion of Garner and the deterrent to recourse to the "curative" federal machinery flowing from the state award of psychic damages as well as lost pay. The dissent also pointed to the state's duplication of the NLRB's back pay remedy and contended that the interest in a complete equitable remedy did not justify the frustration of both "the remedial pattern of the Federal Act"134 and the "unifornity of substantive law so essential to matters having an impact on national labor regulation."135 Finally, the dissent forcefully rejected the significance attached by the majority to the contractual nature of the state action, stating:

[T] he presence or absence of pre-emption is a consequence of the effect of state action on the aims of federal legislation, not a game that is played with labels or an exercise in artful pleading. In a preemption case decided upon what now seems to be discarded principles, the author of today's majority opinion declared: "Controlling

132. The "contract theory" of the union constitution has been criticized as a fiction which disregards the fact that the constitutional provisions are unduly vague, are not the product of consensus or negotiation, and are frequently subject to an unlimited amending power. See, e.g., Summers, Legal Limnitations on Union Discipline, 64 HARv. L. REv. $1049,1054-58$ (1951). It is true that the contract concept does not neatly attach to the relationship between a union and its members. But it is also true that contract is a flexible concept which in many fields (e.g., corporations and public utilities, not to speak of "quasi contracts") is applied to arrangements which are neither negotiated nor consensual. The technical limitations of the contract concept are less important than its usefulness in protecting reasonable expectancies or in restraining, through "public policy" limitations, "abuses" of power. For these purposes, the contract concept, applied in the light of the distinctive relationships involved, appears to be as useful a tool for defining and shaping the mutual responsibilities of the union and its members as any other which is available.

133. 356 U.S. at $618-21$.

134. Id. at 632 .

135. Id. at 631. The dissent also urged that the provision for private remedies in LMRA $\$ 303$ by implication excluded all other private remedies. This contention ignores the fact that $\S 303$ was defining new substantive liaibilities in an area where state law had often excluded any relief. The provision for private actions in such situations is a dubious basis for ousting state power to grant relief for established categories of liability, such as contract liability, operating in an area, such as union internal affairs, which is in general subject to state power. 
and therefore superseding federal power cannot be curtailed by the State even though the ground of intervention be different than that on which federal supremacy has been exercised." Weber v. Anheuser-Busch . . . . 136

There is considerable force to the dissenters' charge that Gonzales is inconsistent with the Court's previous declarations, which had implied an ouster of overlapping state remedies regardless of their labels. ${ }^{137}$ Nevertheless, several distinctive elements in Gonzales invited a departure from, or a reshaping of, earlier pronouncements. First, supervision of internal union affairs has a close functional connection with the policing of union security arrangements. Indeed, the desire of some members to acquire and to retain union membership results from the fact that membership is often a practical, if illegal, condition of employment. This connection renders somewhat artificial a federal-state allocation which grants the states authority to restore membership, but grants to the federal board alone authority to compensate for the economic losses resulting from violation of the rights of membership.

Such a concept of divided jurisdiction involves obvious obstacles to prompt and adequate relief. State relief confined to restoration of membership is often subject to great delays and uncertainties as a result of the requirement that a member exhaust internal union remedies. An expelled member may, moreover, be reluctant to file a charge with the NLRB, because of fear of prejudicing such internal union remedies and being forced to resort to the uncertainties of state litigation. Accordingly, the expelled union member who wishes to remain in a given occupation and to avoid friction with the union leadership may initially resort to internal union remedies. If these are unavailing, his remedy from the Board is subject to the requirement that a charge be filed within six months after the alleged job discrimination occurred or continued. ${ }^{138}$ The delay involved in resort to union remedies and the evidentiary obstacles to showing a continuing violation may create substantial practical difficulties. But even if the expellee surmounts these difficulties and secures a Board cease and desist order, that order, without a restoration of membership, may not as a practical matter effectively protect him against future discrimination that will not be amenable to proof. ${ }^{130}$ Furthermore, even

136. 356 U.S. at 632-33 (dissenting opinion). (Footnote omitted.)

137. The dissenters declared that state and federal courts had been unanimous in denying state power to award damages for employer discriminations (instigated by unions) against nonmembers. Id. at 628-29. But see Selles v. Local 174, Int'1 Bhd. of Teamsters, 50 Wash. 2d 660, 314 P.2d 456 (1957), cert. denied, 356 U.S. 975 (1958); cf. Thorman v. International Alliance of Theatrical Stage Employees, 49 Cal. 2d 629, 634, 320 P.2d 494, 497 (1958) (dictum).

138. LMRA $\$ 10(b)$.

139. In industries with a closed shop tradition, employers may be reluctant to hire or retain a person who is not a umion member even though the union does not press for such job discrimination. Where the union expels a member, such employer reluctance may make proof of resulting job discrimination extremely difficult. It is true that covert 
if the Board's order is effective, an expelled member may wish to have his membership restored for reasons independent of its utility as a defense against discrimination. Thus, if he is to vindicate all of his rights despite the union's unwillingness to correct its error, the alternative to the Gonzales decision would be two proceedings against the union. ${ }^{140}$ These practical shortcomings of the concept of divided jurisdiction give considerable support to the result in Gonzales.

Although that result appears to sanction the overlap condemned in Garner, it should be observed that the states' conceded jurisdiction over the internal affairs of unions, coupled with the competence sanctioned by subsection 14(b), excludes the possibility that damages will be imposed on the basis of standards which involve an encroachment on protected activities. Generally, any job discrimination against an expelled member because of his expulsion will violate the LMRA and thus will not be protected. But in the event that an expellee suffers economic loss as a result of his expulsion without a violation of the LMRA being involved, ${ }^{141}$ state competence over both union security arrangements and internal affairs would prevent the state action from encroaching on protected activities. Accordingly, there is no basis in the Gonzales situation for the fear expressed in Garner, that state action would impose accountability for protected activities. And where such a possibility does not exist, the interest in avoiding state duplication of the federal remedy is a doubtful basis for limiting the states' general competence over internal affairs. ${ }^{142}$

It is significant that in a comparable situation the possible existence of a Board remedy has not excluded alternative forms of relief by courts. In Syres

forms of discrimination against employees whom unions have been forced to restore to membership are also possible, but the employee's possession of a union card would appear to increase somewhat the obstacles to the effectiveness of such tactics.

140. Multiple litigation scarcely promotes a healthy continuing relationship between the union and its members.

141. For example, anl employee expelled from a union for invoking the fifth amendment as to questions concerning alleged membership in the Communist Party may thereafter be discharged by his employer. Whether such a discharge violates the LMRA turns on a hairline distinction, viz., whether it was based on the employee's expulsion from the union rather than the employer's unwillingness to retain employees suspected of being Communists. See Comment, 62 YALE L.J. 954, 964-65 (1953).

Whatever the result under the LMRA, expulsion under such circumstances, if not authorized by the union constitution, could be remedied by a state direction of restoration of membership and (pre-emption aside) by a damage award. Cf. Allen v. Office Employee's Union, 329 P.2d 205 (Wash. 1958).

142. The present no man's land resulting from the Guss case and the NLRB's jurisdictional policies is, of course, another practical aspect of the remedial situation. See notes 170-87 infra and accompanying text. Guss, coupled with a declination of jurisdiction by the Board, would deny the wronged member any compensatory relief if state power were ousted. This anomaly is a pervasive consequence of the no man's land. But in an area so intimately connected with state competence over internal affairs, there are special reasons for limiting the no man's land by recognizing state power. Furthermore, recogniton of the implications of $\S 14$ (b) and its legislative history would constitute an independent basis for Gonzales; but such an approach would require the overruling of Plankinton. 
v. Oil Workers, ${ }^{143}$ the Supreme Court sustained the jurisdiction of the federal courts to grant relief for a breach of the bargaining representative's duty of fair representation despite the fact that (1) the breach involved might have been an unfair labor practice, ${ }^{144}$ and (2) even in the absence of an unfair labor practice, the Board could have decertified the representative if it did not abandon its discriminatory representation. ${ }^{145}$ It is not easy to see why a partial Board remedy of doubtful effectiveness should be fatal to state power in the Gonzales situation when such a remedy does not oust the federal courts of jurisdiction over discriminatory representation.

Subsection $14(\mathrm{~b})$ is relevant not only to consummated hiring arrangements which violate state laws operative under that subsection, but also to antecedent pressures directed at securing such arrangements. Where such pressures appear to violate the LMRA as well as state law, the Court, without any explicit consideration of subsection $14(\mathrm{~b})$, has invalidated state injunctive relief. ${ }^{146}$ It is true that Garner on the surface appears to exclude such state action. But the applicability of Garner is questionable because subsection 14(b) and its legislative history suggest, as already indicated, that state policy as to union shop arrangements was to be given paramount effect. Such

143. 350 U.S. 892, reversing per curiam 223 F.2d 739 (5th Cir. 1955).

144. Professor Cox has urged that union bargaining which violates the duty of fair representation should be held to be a violation of $\$ 8$ (b) (3) of the LMRA. Cox, The Duty of Fair Representation, 2 VmL. L. REv. 151, 172-75 (1957). Although recognizing the technical difficulties involved, Cox has not considered whether more vigorous enforcement by the Board of the duty of fair representation would interfere with its other functions. The problem results not merely from the great delays already involved in Board proceedings, but also from the fact that the most flagrant and the most easily identifiable departures from fair representation involve racial discrimination. Vigorous intervention in this area by the Board might provoke budget cutting by Congress; hostility from the Southern bloc might be intensifled by the absence of clear statutory authority. This political factor is also passed over by Professor Wellington, who, moved by the Board's expertise, recommends a statute conferring responsibility on the Board for enforcing the duty of fair representation. Wellington, Union Democracy and Fair Representation: Federal Responsibility in a Federal System, 67 Y ALE L.J. 1327, 1359 (1958). But reliance on the "Board's expertise," which is easily and frequently exaggerated, may" merely obscure the enormous difficulties involved in policing the duty of fair representation, except where flagrant racial discrimination is involved. Snce it is likely that more vigorous enforcement of that duty would be directed largely at such discrimination, a judicial remedy may be preferable to an administrative one because the former remedy is dispersed and is less vulnerable to budgetary reprisals. Although the judicial remedy suffers from the absence of government-supplied counsel, private counsel may be available -at least in the area of racial discrimination-even though individual litigants may not be able or willing to pay the fees. Furthermore, since the basic problem in this arca appcars to be inadequate preventive relief, the possible bias of juries in actions for danages may be put aside.

145. See Syres v, Oil Workers, 223 F.2d 739, 747 (5th Cir.) (Rives, J., dissenting) (by implieation), rev'd per curiam, 350 U.S. 892 (1955).

146. In Farnsworth \& Chambers Co. v. Local 429, Int'1 Bhd. of Elec. Workers, 299 S.W.2d 8 (Tenn. 1957), picketing to secure the employment of union members exclusively was enjoined as a violation of the Tennessee "right-to-work" law. The Supreme Court reversed per curiam, 353 U.S. 969 (1957), citing Weber and Garner. The underlying facts together with these citations suggest that the basis for the Court's decision was the overlap between the state injunction and the NLRB's remedy for violation of LMRA § \& (b) (2). 
paramount authority should apply not only to consummated hiring arrangements, but also to antecedent pressures directed toward their achievement.

Where antecedent pressures violate state law without violating the LMRA, there are even stronger grounds for recognizing state competence to grant injunctive relief. The denial of such competence would result in a selfdefeating jurisprudence which would command an employer not to enter into a union security agreement while denying him any relief against pressures designed to compel the execution of such an agreement. ${ }^{147}$

It is true that the recognition of state competence would involve the risk of restraint by state tribunals of activities which might be found to be protected under the national scheme, a risk which might be especially acute in states where enactment of "right-to-work" laws may reflect antiunion attitudes. Restraints on protected activity might occur, for example, where the state tribunal determined, on the basis of conflicting or ambiguous evidence, that union pressure was directed at securing hiring arrangements proscribed by state law, but where the NLRB might reasonably reach a contrary conclusion. Subsection 14(b) tolerates such risks with regard to state adjudications concerning the validity of the executed arrangements. If appropriate weight is given to the policy and legislative history of subsection $14(\mathrm{~b})$, it is not easy to see why such risks should be fatal when antecedent union pressures are involved.

\section{State Laws of General, Application}

Some commentators, although in general urging a limited role for state power over labor relations, have suggested that for pre-emption purposes a distinction should be drawn between labor regulations "as such" and "state regulation of general application." The thrust of this position, which may be illustrated by the views of Professor Cox, ${ }^{148}$ appears to be that the states should be free to enforce general regulations even though such enforcement involves conduct which is or might plausibly be prohibited or protected under the national scheme. The proposed formula would, of course, avoid the regulatory gaps and the drastic impairment of state power which would result if all state law of general application were foreclosed whenever it impinged on labormanagement relations.

The formula, however, involves several difficulties. First, it rests on a classification scheme which, as Professor Cox recognized, ${ }^{149}$ would be extremely difficult to apply to the wide variety of state regulations involved.

147. For illustrations of this problem see Asphalt Paving, Inc. v. International Bhd. of Teamsters, 181 Kan. 775, 798, 317 P.2d 349, 366 (1957) (concurring opinion); Douglas Aircraft Co. v. Local 379, Int'l Bhd. of Elec. Workers, 247 N.C. 620, 627-28, 101 S.E.2d 800, 806 (1958).

148. See Cox, Federalism in the Law of Labor Relations, 67 HARv. L. Rev. 1297, 1324-31 (1954).

149. Ibid. 
Secondly, it appears to dilute the values of uniformity and the avoidance of fine lines of distinction which have been urged in support of comprehensive preemption. These difficulties will be examined and then the predictive value of this formula will be appraised in the light of the Supreme Court decisions.

The common law of labor relations began as a branch of the law of torts and emerged in the twentieth century as a distinct body of regulation. ${ }^{150}$ The common law basis for state prohibition of stranger picketing for recognition typically is the general tort doctrine that intentional interferences with advantageous relationships are tortious unless justified and that a union's desire to spread organization is not sufficient justification. ${ }^{151}$ It can be urged that such a state regulation is merely a general application of tort law to labor-management relations. But, Professor Cox urges, the application of the tort doctrine involves a social appraisal of the conflicting interests of the union, the employer, and the community in the labor controversy. Since the existence of a labor dispute is central to the social appraisal involved, the application of tort doctrines to make the union's conduct actionable is labor regulation "as such."152 The critical element in Professor Cox's classification thus appears to be that liability depends on an appraisal of the distinctive elements of labor-management relations in the light of other competing interests or objectives.

The basic difficuly with such a formula is that substantially the same social appraisal is involved in any rational legislative or judicial determination that any general regulation should be controlling in the labor-management context. For example, a union which has entered into price fixing agreements with employers or into agreements excluding the purchase of out-of-state goods is indicted under a broad state antitrust law condemning all arrangements and conspiracies in restraint of trade. The disputed issue is whether the distinctive aspects of the union movement justify a refusal to apply a general standard in the context of labor-management relations. Although the technique for resolving such an issue will depend on whether a statute or a common law standard is controling, its resolution will turn on what force should be given to the union's claim that there is a social justification for exempting it from a general standard which on the surface appears to be applicable. It is precisely such a claim which must be adjudicated when a union urges its "right" to engage in stranger picketing or to induce the breach of a contract between an employer and another union. In view of the basic similarity of the social appraisal involved in the antitrust and prima facie

150. See 1 Harper \& J AMES, TorTs $\$ 6.13$, at 523-26 (1956).

151. See, e.g., Keith Theatre, Inc. v. Vachon, 134 Me. 392, 403-04, 187 Atl. 692, 697 (1936). The rationale for subsequent decisions reaching a similar result has naturally been affected by the pin-pointing of the issues involved, by frequent litigation as well as by state and federal statutes. See generally Annot., 11 A.L.R. 2d 1338 (1950). (1954).

152. Cox, Federalism in the Law of Labor Relations, 67 HaRv. L. Rev. 1297, 1324 
tort situations, the distinction between labor regulation as such and regulations of general application appears to be essentially verbal; for whenever the state has concluded that a given rule should control labor relations despite the distinctive elements involved, there is no analytical basis for determining whether the state regulation deals with labor relations as such or is a rule of general application applied to labor-management relations.

The difficulty of classification is illustrated by Professor Cox's criticism of the decision by the Missouri Supreme Court in the Weber case. ${ }^{153}$ His criticism rested on the contention that the court, in holding the restraint in question unlawful under the Missouri antitrust law, relied on the following ground:

... under the terms . . . sought to be imposed by the Union, persons employed by or seeking to work for the ... construction contractors in moving, erecting or installing machinery .... would be compelled to forego representation by their present bargaining agent, the Millwrights' Union . . . and become affiliated with the Machinists' Union in order to retain their employment with such contractors . ....$^{154}$

Accordingly, Professor Cox concluded that the underlying issue was made to turn "on balancing the interests of employers, employees, and unions in organization or collective bargaining, [and that under such circumstances] the states should be no more free to apply antitrust laws than statutes or court decisions avowedly based upon those considerations."155

Under Professor Cox's view, the rhetoric used by the Missouri Supreme Court seems to be the decisive consideration in denying state competence. Plainly, state courts and legislatures, determined to uphold state power, will be able to accommodate themselves to the semantic demands of the situation. Indeed, other passages in the Missouri opinion, not referred to by Professor Cox, if taken at face value, support the conclusion that Missouri was implementing a general policy against restraint of trade and not labor regulation "as such." Thus the court emphasized throughout that the union was seeking to force the company to become a party to a conspiracy against independent contractors and their millwright employees, ${ }^{158}$ i.e., the union was seeking an agreement which would exclude from the market all contractors not under contract with the union. Such agreements, which may be viewed as attempts at permanent exclusion from a market, can plausibly be said to involve the basic evils which antitrust regulation is designed to suppress. It is worth

153. Anheuser-Busch, Inc. v. Weber, 364 Mo. 573, 265 S.W.2d 325 (1954), rev'd, 348 U.S. 468 (1955).

154. Id. at 579,265 S.W.2d at 328.

155. Cox, Federalism in the Law of Labor Relations, 67 HARv. L. REv. 1297, 1330 (1954).

156. 364 Mo. at 579-82, 265 S.W.2d at 328-30. 
recalling that the basic dispute involved in Weber had moved a national administration, not unfriendly to labor, to institute antitrust proceedings against a union seeking the same kind of exclusive arrangements condemned by Missouri in the Weber case. ${ }^{157}$

These considerations underscore the difficulties with the contention that Missouri's regulation should have been invalidated because the Missouri judgment resulted from balancing the interests involved in labor regulation. This contention is no more persuasive than the claim that Missouri attempted to balance the interests involved in the application of general regulation in a specialized context, namely, labor-management disputes. Nor is there anything in the application of Professor Cox's formula to the Weber case which affords a useful guicle for determining when general regulation, such as antitrust regulation, will for pre-emption purposes be treated as general regulation rather than as labor regulation "as such."

Although, as indicated inore fully below, the formula in question may be a useful expedient for avoiding the drastic displacement of a broad range of state regulation, it involves a serious risk of making pre-emption a game played with labels which do not disclose the determinants of decision. In this connection, it is instructive to compare Professor Cox's treatment of Weber with his treatment of a general regulation applied by a state to invalidate the erection of geographical trade barriers by a umon through agreements with employers to boycott goods not produced in a given locality. Professor Cox, despite his approval of the foreclosure of state power in Weber, supports the recognition of state competence in the latter situation. ${ }^{158}$ It is not easy to see the basis for this difference in result. In both situations the unions are attempting to maximize employment opportunities for their members by permanently excluding certain enterprises from the market. ${ }^{150}$ In both situations similar arrangements among employers would appear to violate state antitrust laws. Accordingly, the ultimate issue faced by state governments

157. See United States v. Hutcheson, 312 U.S. 219 (1941).

158. Cox, Federalism in the Law of Labor Relations, 67 HARv. L. Rev. 1297, 1330-31 (1954). The example is suggested by Allen-Bradley Co. v. Local 3, Int'1 Bhd. of Elec. Workers, 325 U.S. 797 (1945), and Mayer Bros. Poultry Farms v. Meltzer, 274 App. Div. 169, 80 N.Y.S.2d 874 (1st Dep't), appeal denied, 274 App. Div. 877, 83 N.Y.S.2d 228 (1st Dep't 1948). In view of the possible overlap between state and federal antitrust laws in the situations described in the text, it should be noted that national antitrust legislation has generally not been viewed as pre-empting state regulation. E.g., Standard Oil Co. v. Tennessee, 217 U.S. 413, 421-22 (1910) ; Commonwealth v. McHugh, 326 Mass. 249, 264-68, 93 N.E.2d 751, 761-64 (1950). As to state antitrust law applied to labor-management relations, this view merits re-examination beeause of the interlacing of federal labor statutes and the Sherman Act in United States v. Hutcheson, 312 U.S. 219 (1941), and the pre-emption of state power over labor relations.

159. It is true that in the Weber situation the particular exclusionary arrangements would be terminated after the appropriate shift in the union status of the excluded enterprises' employees. But such a shift might touch off new exclusionary pressures on the part of the rival union. Furthermore, in the ease of exclusion based on location, exclusion presumably could also be ended by plant relocation which would bring the enterprise within the orbit of the union enforcing the exclusionary arrangements. 
in each case is whether a union's interest in maximizing employment for its members justifies a relaxation of the general rules against restraint of trade. It is difficult to see anything in the distinction between labor regulation "as such" and general regulation which warrants different decisions as to state power in these two situations. Nor do the interests emphasized in Garner, such as centralized administration of the national act and avoidance of overlap, warrant such disparate results. Thus, if the unions struck for each of the objects involved in these cases, there would in each case be similar possibilities of an overlap between state and federal remedies. ${ }^{160}$ Consequently, all of the arguments against state power invoked in Garner would be equally applicable to both situations.

It is difficult to avoid the conclusion that Professor Cox's formula will spawn a new set of slippery distinctions, thereby frustrating one of the purposes behind his general endorsement of a broad doctrine of federal pre-emption. Furthermore, that formula also threatens the other values invoked to support such a doctrine, namely, uniformity and preservation of the federally created balance between labor and management. These consequences of the formula are interesting not only in their own right but also-and more importantlybecause the necessity of invoking such a formula to avoid drastic impairment of state power puts into question the basic presupposition behind a broad and abstract rule of federal pre-emption.

The Court's decisions which bear on the proposed distinction between labor and general regulation have not accorded significant weight to the fact that state regulation was of general application. At most, the Court has treated that factor as reinforcing other considerations invoked to sustain state power. ${ }^{161}$ As already indicated, that distinction will not serve to explain the Court's disposition of Weber, nor its recent decision, the Oliver case, ${ }^{162}$

160. A strike in both the Weber and the geographical boycott situation might involve a violation of LMRA \$ 8(b) (4) (A). See generally Koretz, Federal Regulation of Secondary Strikes and Boycotts-Another Chapter, 59 CoLvM. L. REv. 125 (1959).

161. See, e.g., International Ass'n of Machinists v. Gonzales, 356 U.S. 617 (1958) ; United Constr. Workers v. Laburnum Constr. Corp., 347 U.S. 656 (1954).

162. Local 24, Int'1 Bhd. of Teamsters, AFLCIO v. Oliver, 358 U.S. 283 (1959). In Oliver, the Teamsters Union and certain truckers, after bargaining on a multi-employer and multi-state basis, entered into an agreement fixing mininum rental rates and other terms of leases under which "owner-operators" were to operate their own vehicles for the truckers. The Ohio courts held that this agreement was not an unfair labor practice, that it violated the state's antitrust law, and that it was, accordingly, enjoinable. Oliver v. All-States Freight, Inc., 42 L.R.R.M. 2024 (Ohio Ct. App. 1957), aff'd nem. sub non. Oliver v. A. C. E. Transp. Co., 167 Ohio St. 299, 147 NE.2d 856 (1958). The Supreme Court, dismissing as immaterial Ohio's characterization of its regulation as "antitrust," reversed. 358 U.S. at 297. The Court found (1) that the challenged provision was designed to protect the employees' wage rates from being indirectly undermined by rental rates below the "owner-operators" operating costs, and (2) that bargaining concerning the rental rates was mandatory under the LMRA. Accordingly, it invalidated the Ohio decree as an interference with federally protected collective bargaining.

Oliver raises the following questions, among others: (1) Could the Court properly find that bargaining over the owner-operators' rates was mandatory without a prior determination that the owners were not independent contractors, which characterization 
which was decided after the writing of this article and which can only be briefly referred to below. Indeed, in Gonzales the dissenters pointed to broad language in Weber which rejected as irrelevant the contention that the state was applying a rule of general application. ${ }^{103}$ Conversely, the fact that Wisconsin, in the Kohler case, predicated its restraint of violence on a labor relations statute did not operate to invalidate state action. ${ }^{104}$

Perhaps the most striking instance of the Court's disregard of the distinction in question and its invalidation of general regulation is its treatment of state cases involving enforcement of so-called "hot cargo" clauses entered into by common carriers and unions representing their employees. Such clauses frequently purport to give the carrier's employees the right not to cross picket lines and to refuse to handle "hot cargo," defined to include nonunion materials or materials produced by, or consigned to, another employer with whom the contracting union or some other union has a controversy. Hot cargo clauses appear plainly to be inconsistent with the historic duty of common carriers to serve without discrimination, a duty which arises under state as well as federal transportation law. Interference with that duty by private nonunion groups could be remedied by state injunctions. Where such injunctions or similar relief have been directed at unions or employers who are

would have excluded them from coverage of the act? (Cf. NLRB v. Wooster Division of Borg-Warner Corp., 356 U.S. 342 (1958), and the Garner case.) Mr. Justice Whittaker apparently assumed not and dissented solely on the basis of his conclusion that the owneroperators were independent contractors. 358 U.S. at 297. (But as to that conclusion, compare $\$ 4$ of the challenged provisions. Id. at 298.) His dissent leads to question (2) : Given Garner's emphasis on "primary interpretation," may state courts, or indeed the Supreme Court, characterize, prior to an NLRB determination, ostensible independentcontractors as genuine ones? Since this characterization often marks the line between illegal price fixing or protected collective bargaining, question (2) is crucial to the validity of a wide range of state antitrust activity. (3) Even though state tribunals properly conclude that no substantial independent-contractor question is involved, are they to be prevented from applying local antitrust laws to collective bargaining agreements on the ground that there is a reasonable or plausible possibility that a particular agreement may be appropriate to protect employees' rates or jobs and hence may be protected under the national statute? (4) Will the exclusion of state authority extend to agreements even though they deal with matters not the subject of mandatory bargaining, on the ground that \$ 8(d) of the LMRA also "protects" such agreements? (5) Will agreements resulting from bargaining protected by the LMRA be insulated against federal as well as state antitrust laws? Or, conversely, will the violation of federal antitrust laws result in the withdrawal of LMRA protection? In this connection, the Court in Oliver pointed to the absence of any contention that the agreements went beyond the limits of federal antitrust immunity set by Allen-Bradley Co. v. Local 3, Int'1 Bhd. of Elec. Workers, 325 U.S. 797 (1945). Generally, conduct which contravenes another federal statute is unprotected under the LMRA. But this generality does not identify the agency which is to accommodate two competing statutory policies. (Compare the jurisdictional renvoi between the Board and the ICC concerning hot cargo clauses, described in note 165 infra.) Startling as the result may seem, it is conceivable that federal antitrust prosecutions of labor-management arrangements may depend on, or be limited by, determinations under the LMRA concerning the independent-contractor issue or the scope of federally protected bargaining. Cf. Federal Maritime Bd. v. Isbrandtsen Co., 356 U.S. 481, 497-98 (1958); United States v. Hutcheson, 312 U.S. 219 (1941). But cf. United States v. Radio Corp. of America, 27 U.S.L. WEEK 4179 (U.S. Feb. 24, 1959) ; Local 1976, United Bhd. of Carpenters, AFL v. NLRB, 357 U.S. 93, 109-11 (1958).'

163. See text accompanying note 136 sipra.

164. See text accompanying notes 90-91 sitpra. 
parties to hot cargo clauses, the Court has, however, reversed, per curiam. ${ }^{165}$ Furthermore, the Court has chosen not to notice that such cases involve three separable, though related, issues: (1) Whether a union may enlist the help of the employees of employer $B$, a common carrier, in order to secure the union's demands against employer $A$, the "primary employer." This issue involves the scope of the secondary boycott provision of LMRA subsection $8(\mathrm{~b})(4)$ (A). (2) Whether a hot cargo clause is valid under the general transportation law of the state-an issue which has been pin-pointed in state litigation by requests for a declaration of the invalidity of such clauses. ${ }^{166}$ (3) Whether a state injunction may require not only the carriers but also their employees not to interfere with the rendition of equal services to the primary employer.

A persuasive argument could be made that state determination of the second issue involves the effect of a transportation regulation of general application and not labor regulation "as such." A similar argument could be made as to an injunction running against the carriers' employees and prohibiting interference with the carriers' discharge of their obligations, although the argument in this context involves greater difficulties. ${ }^{107}$ Indeed, the Court,

165. E.g., Teamsters Union v. Kerrigan Iron Works, Inc., 353 U.S. 968 (1957), reversing per curiam Kerrigan Iron Works, Inc. v. Cook Truck Lines, Inc., 296 S.W.2d 379 (Tenn. Ct. App. 1956). A comparison of the Court's apparent refusal to separate these issues in pre-emption cases with the ICC's approach is instructive. The ICC has declared that the validity of agreements between unions and carriers is a matter solely within the NLRB's competence. (At about the same tinie, two of the three members of the Board who declared hot cargo clauses executed by common carriers invalid justified this result by reference to the Interstate Commerce Act and the ICC rulings thereunder. Genuine Parts Co., 119 N.L.R.B. No. 53 (1957)). The ICC, although deferring to the Board's expertise in labor matters, has asserted its own jurisdiction over the conduct of common carriers in relation to their public obligations under the Interstate Commerce Act, without regard to terms included in their collective bargaining agreeinents. The Commission has decided that a carrier's refusal to provide service because of its hot cargo clause violates the Interstate Commerce Act. Galveston Truck Line Corp. v. Ada Motor Lines, Inc., 73 M.C.C. 617 (1957). Since the concurrent jurisdiction of the states over common carriers has been recognized, Pennsylvania R.R. v. Puritan Coal Mining Co., 237 U.S. 121 (1915), it is difficult to see why the states, any more than the ICC, should be disabled from enforcing their general policy against a carrier merely because of the carrier's involvement in a labor dispute. at 382 .

166. See Kerrigan Iron Works, Inc. v. Cook Truck Lines, Inc., supra note 165,

167. Only a brief reference to the complex argument involved is possible here. Where the employees of a secondary employer (here, the carrier) refuse to cross a picket line adjacent to a primary employer (here, the shipper or consignee) or refuse to handle or process the primary employer's goods, the employees' refusal is, unless sanctioned by a contract, unprotected, i.e., the earrier could lawfully discharge them. Robert $H$. Snow, 107 N.L.R.B. 242 (1953); cf. NLRB y. Rockaway News Supply Co., 345 U.S. 71 (1953). In the common carrier context, the validity of such a contract is uncertain. See Local 1976, United Bhd. of Carpenters, AFL v. NLRB, 357 U.S. 93, 108 (1958). Furthermore, the coalescence of labor and transportation policy complicates the issue of what federal tribunal has jurisdiction to pass on the issue of validity. See note 165 supra. Insofar as the states are concerned, their jurisdiction to enforce the carrier's duty to serve without discrimination was confirmed, prior to the enactment of the LMRA. Pennsylvania R.R. v. Puritan Coal Mining Co., 237 U.S. 121 (1915). Insofar as relations between the carrier and its customers are concerned, state competence would appcar to extend to the validity or effect of a hot cargo clause. Even if Textile Workers v. Lincoln Mills, 353 U.S. 448 
in dealing with the significance of a hot cargo clause as a defense to a charge of violation of the LMRA's ban against secondary boycotts, explicitly recognized that the impact of a hot cargo clause on the carrier's obligation to serve was a matter of transportation, rather than labor, policy. ${ }^{108}$ In dealing with state power over hot cargo clauses the Court did not, however, consider the separation of the transportation issue from the related issues, but instead, by cryptic per curiam decisions, nullified the state action in toto.

If, as the foregoing discussion suggests, the label or the generality of state regulation is not a passport to validity, either all general regulation impinging on labor-management relations will be invalidated unless the challenged regulation falls within established exceptions to the general rule of pre-emption, or supplementary criteria will have to be developed. Total invalidity would involve so drastic an attrition of state power and would leave such regulatory gaps as to be almost unthinkable. It would, for example, be bizarre indeed to strike down FEPC regulation, antitrust regulation, transportation regulation, and various forms of safety regulation merely because such regulation limited the objectives sought in collective bargaining. On the other hand, the development of supplementary criteria which will give mcaningful guidance to those affected and to state tribunals will be no easy task. Perhaps, all that can be said is that the decisive factor will be a judgment

(1957), has displaced state law, state competence to apply federal law to collective bargaining agreements may be upheld. See part II of this article, which will appear in the February issue of this Review.

State attempts to regulate employee activity on the ground that it defeats the state transportation policy would, however, involve the possibility of overlap with federal remedies or encroachment on federally protected activities. Nevertheless, in this context, whether the employee conduct is protected depends on the validity of tbe hot cargo clauseand that issue could be characterized as dominantly one of transportation policy although labor policy is also "incidentally" involved. The crucial bearing of transportation policy on the issue might justify reliance on Briggs-Stratton as authority for state determination of whether the employees' refusal to serve was federally protected. A negative determination would be the basis for state competence to enjoin employee interference with the carrier's discharge of its duty to serve, i.e., an injunction requiring the employees to cross the picket line. Whether state power should be exercised in a given situation and the possible impact of anti-injunction legislation are, of course, separate questions.

A final complication results from the puzzling proviso of $\$ 8(\mathrm{~b})(4)$ of the LMRA which states that "nothing contained in this subsection [(b)] shall be construed to make unlawful a refusal by any person to enter upon the premises of any employer (other than his own employer) if the employees ... are engaged in a strike ratified ... by a representative of such employees whom such employer is required to recognize . ..." (Emphasis added.) This complex provision cannot be fully treated here. It is worth noting, however, that the italicized language implies that there may be sources of restraint against respect for picket lines other than those embodied in $\$ 8(\mathrm{~b})(4)$. Furthermore, although the prohibition against involuntary servitude might bar judicial compulsion to force employees to cross picket lines, that prohibition would not preclude judicial restraint of actions by unions to bring about a boycott by the employees of common earriers. The problems involved in commanding employees of common carriers to serve without discrimination resemble, it may be noted, those involved in compelling employees to serve others without regard to their race or creed.

This footnote is not offered as a solution of the problems involved, but only as a suggestion that they do not seem appropriate for per curiam disposition. (1958).

168. Local 1976, United Bhd. of Carpenters, AFL v. NLRB, 357 U.S. 93, 110-11 
as to the impact of the state regulation on the central purposes of the national act. For example, FEPC regulation, barring the use of either collective bargaining or employer-determined hiring practices as an instrument of racial discrimination, might well be treated differently from state-imposed wage ceilings or from general licensing requirements applicable to all agents of out-of-state organizations who solicit dues or the power to represent persons in their economic relations. ${ }^{169}$ Different treatment of those situations would appear to be justified because the effect of FEPC legislation seems to be more remote from the central objectives of the union movement and seems to involve less of a threat to collective bargaining and employee freedom to choose representatives than do the other forms of state regulation referred to above. It is plain, however, that difficult issues of degree are involved and that there is a genuine danger that resolution of these issues will require the Court to engage in the slippery game of passing on the wisdom of the state action or the propriety or conventionality of the union objectives. But similar risks are a familiar and a possibly inescapable aspect of federalist accommodation.

In this process of accommodation, the fact that the state regulation applies generally to nonunion as well as union activity, although not decisive, is not wholly irrelevant. The generality of the regulation may, together with other considerations, reflect the importance which a state attaches to the values involved. The requirement of generality may, moreover, curb regulations devised for the sole purpose of creating roadblocks to effective union organization or collective bargaining. But the reality of such a curb would, of course, depend on whether drafting skills or selective enforcenent policies could be exploited to dress up antiunion legislation as general regulation. These considerations, which suggest that in some situations weight may be attached to the fact that regulation is of general application, are not offered as neat logical solutions for difficult questions of degree. They are essentially pragmatic limitations both on the range of state power which will be validated and on the otherwise broad sweep of current pre-emption doctrines.

\section{NLRB Self-Limitation and State Competence}

Guss v. Utah Labor Relations Bd. ${ }^{170}$ involved the most dramatic attrition of state power in the area of labor relations. In Guss, the Court, with Justices Burton and Clark dissenting, ruled that the NLRB's ad hoc decision not to handle a specific case or its general standards limiting its statutory jurisdiction did not result in state authority to handle matters thus excluded from the Board's effective jurisdiction. The proviso added to Subsection 10(a) of

169. For a case dealing with the latter situation see Hill v. Florida ex rel. Watson, 325 U.S. 538 (1945).

170. 353 U.S. 1 (1957). 
the Wagner Act by Taft-Hartley provided, the Court concluded, the only method by which the states could be authorized to handle matters within the Board's statutory jurisdiction. That proviso empowered the Board to cede jurisdiction over certain cases to a state agency provided that there was conformity between the state regulation and the national statute. The Court read the proviso as excluding state action in cases where the Board, instead of ceding its jurisdiction, declined to exercise it. ${ }^{171}$

No state has been able to meet the requirements of the proviso, as interpreted by the NLRB. Accordingly, the result of Guss and the Board's policy of selective jurisdiction is a notorious no man's land in which conduct unlawful under both federal and state law is not restrained by the Board and cannot constitutionally be restrained by the states. This result, which under any circumstances would be indefensible as a matter of policy, is a grotesque paradox in the context of the LMRA. That statute in general expanded regulation of labor relations. It reflected, moreover, both in its provisions ${ }^{172}$ and in its legislative history ${ }^{173}$ a special concern for the labor relations of smaller enterprises. And yet all regulation of the labor relations of such enterprises is suspended unless they fall within the ill-defined and shrinking category of businesses which do not "affect commerce" or unless exceptions to pre-emption, e.g., cases involving violence, are applicable. This result is an eloquent reminder of the difficulties produced by the failure of Congress to bring responsible craftsmanship to bear on the problems of federalism implicit in the LMRA. ${ }^{174}$

Guss has sharpened for both the national government and state tribunals a set of problems the solution of which will determine the extent of effective labor regulation in the present no man's land and the scope of state authority over "small business." These essentially national problems include: (1) The validity of the Board's jurisdictional standards, which for some time have been challenged as beyond the Board's statutory authority ${ }^{175}$ and which, after Guss,

171. The alternatives to the Giss result have been the subject of exhaustive discussions, which will not be recapitulated or appraised here. See Tobriner \& Grodin, TaftHartley Pre-emption in the Area of NLRB Inaction, 44 CALIF. L. Rev, 663 (1956).

172. See, e.g., LMRA \& 8(b) (4) (A), which proscribes union pressure to force an employer or self-employed person to join a union. This problem typically arises in connection with small businesses.

173. For example, the late Senator Taft declared during the legislative debate that "the larger employers can well look after themselves, but throughout the United States there are hundreds of thousands of smaller employers, smaller businessmen, who, under the existing statutes, have come gradually to be at the mercy of labor union lcaders ...." 2 LIGIS. Hist. 1005.

174. In Guss, the Court appeared to invite legislation changing its decision. 353 U.S. at 11. Legislative efforts have failed in part because they have become enmeshed with larger differences concerning the content of a desirable national labor policy.

175. See Note, The Discretionary Jurisdiction of the NLRB, 71 HARv. L. REv. 527. 532-34 (1958). The Court was careful to point out in Gilss that it was not passing on the validity of the Board's declining jurisdiction on an ad hoc basis or on the basis of its general yardsticks. The general standards based on dollar minima might be invalidated 
have been challenged as a violation of the fifth amendment. ${ }^{176}$ (2) Revision by the Board of its jurisdictional standards, with a view to reducing or eliminating the no man's land. ${ }^{177}$ (3) The content of remedial legislation in the area "affecting commerce": (a) Should Congress require the Board to exercise jurisdiction over every enterprise subject, as a matter of constitutional law, to the commerce power? (b) Should the Board be authorized to limit its own jurisdiction either by general standards announced in advance or by ad hoc determinations? (c) Should Congress determine the limits of the Board's jurisdiction regardless of how those limits are defined? (d) Should the states be able to act independently of the national policy in the area of declined jurisdiction? (e) Should state action be subjected to the national policy through review by the NLRB or by the federal courts, with frivolous review deterred by the assessment of counsel fees against the culpable party?

Although an extensive discussion of these problems is beyond the scope of this article, ${ }^{178}$ a few general comments may be in order. First, it is plain that the Court cannot work out viable solutions. The Court can command the Board to occupy the no man's land, but only Congress can supply the necessary funds. Although the current Congress has increased appropriations for the Board, ${ }^{179}$ Congress, faced with a growing deficit and international tensions,

without necessarily outlawing the ad hoc declinations of jurisdiction. The Board's practice of ad hoc declination was established under the Wagner Act and was not disturbed by Taft-Hartley. Although an ad hoc policy would theoretically permit the board to consider the seriousness of the abuse involved in a particular case, the Board's case load might make this possibility largely academic. Such a policy would, however, avoid public announcement of the fact that a federal statute could be violated with impunity. Former Board Chairman Madden has argued that prior announcement of jurisdictional standards lets the cat out of the bag. Madden, Comment and Appraisal, 16 Онго ST. L.J. 427, 432 (1955). But the ad hoc policy would revive the uncertainties and the dubious use of staff which the jurisdictional standards were desiguied to eliminate.

176. See, e.g., Johnson v. Grand Rapids Bldg. Trades Council, 42 L.R.R.M. 2680 (Mich. Cir. Ct. Sept. 2, 1958), where the exercise of state power was rationalized as necessary to avoid a violation of due process. But this approach is inconsistent with the Supreme Court's disposition of Guss. See also Ex parte Twedell, 309 S.W.2d 834 (Tex. 1958); Heiser Ready Mix Co. v. International Bhd. of Teamsters, Case I, No. 6552, Cw-244, Decision No. 4780, at 21, Wis. Employment Relations Bd., June 2, 1958. Federal courts, on due process grounds or on the basis of statutory interpretation, may direct the General Counsel and the NLRB to exercise jurisdiction fully or at least to replace jurisdictional standards with an ad hoc approach. See Heiser Ready Mix Co. v. Fenton, 42 L.R.R.M. 2735 (W.D. Wis. July 9, 1958), where the Board's General Counsel was directed to investigate charges of unfair labor practices even though the Board's jurisdictional yardsticks were not satisfied. See also Hotel Employees v. Leedom, 358 U.S. 99 (1958); Office Employes v. NLRB, 353 U.S. 313 (1957), 57 ColuM. 'I. REv. 1029; Pederson v. NLRB, 234 F.2d 417 (2d Cir. 1956); Hourihan v. NLRB, 201 F.2d 187 (D.C. Cir. 1952), cert. denied, 345 U.S. 930 (1953).

177. The Board, explaining its action as a result of the Guss decision, announced proposed changes in its jurisdictional standards. NLRB Statement R-570, July 22, 1958, 1 LAB. REL. REP. (42 L.R.R.M.) 363 (1958). According to Chairman Leedom's testimony before a House subcommittee on June 10, 1958, the new standards would include $20 \%$ of the cases now rejected. I LAB. REI. REP. (42 L.R.R.M.) 185 (1958). The proposed changes, with further changes expanding the Board's effective jurisdiction, were put into effect on October 2, 1958. 1 LAB. REL. REP. (42 L.R.R.M.) 633 (1958).

178. For a comprchensive discussion of some of these problems see Note, The Discretionary Jurisdiction of the NLRB, 71 HARV. L. REV. 527 (1958).

179. See 1 LAB. REL. REP. (42 L.R.R.M.) 368 (1958). 
is an unpredictable provider. The net result of judicial invalidation of the Board's current policies might mean theoretical relief for employees and employers involved in small enterprises which "affect commerce" but a denial of effective relief to all employees and employers by increased delays in an area where a meaningful remedy must be a prompt one. Such invalidation is superficially appealing because it would extend protection to those groups which need it most. But there is a danger, and perhaps a controlling one, that equality of remedy might in practice be the equalization of chaos.

The problems which would be raised by requiring the Board to exercise jurisdiction over all of the enterprises affecting commerce obviously cannot be solved solely by larger appropriations. More money and more staff will not eliminate, and may indeed accentuate, the difficulties and delays inherent in an effort by a five-man board in Washington to regulate up to the periphery of national competence. ${ }^{180}$ Changes in the Board's administrative structure, ${ }^{181}$ coupled with a review and revision of rigid, time-consuming, and unproductive statutory and admimistrative requirements, ${ }^{182}$ may perhaps make it possible for the Board to deal with a substantially increased load.

Beyond these questions of efficiency there are naturally touchy and imponderable questions of faith suggested by slogans such as "states' rights" and "uniformity in a national economy." In this connection it is again useful to keep in mind the difference between the exercise of federal power to enforce minimal standards throughout the sphere of national competence and the exercise of that power to exclude all state regulation. If the federal power is in its sphere to be exclusive as well as paramount, the vitality of the federalist ideal together with practical pressures may be strong enough to exclude federal power entirely from smaller business, thereby jeopardizing minimal federal objectives in that area. Thus, the accommodation in the no man's land may well depend on the distribution of federal and state power throughout the whole area of labor relations.

The problems of federal-state accommodation in the no man's land and elsewhere plainly eall for congressional solution. They involve clashes in basic outlooks and values, the resolution of which generates enormous strains on the Court-strains on its internal unity and on public acceptance of the finality and

180. See 1 Lab. ReL. Rep. (42 L.R.R.M.) 492, 498 (1958).

181. A Board of increased size could be divided into two sections : one entrusted with representation eases and the other with unfair labor practice cases. The interrelationships between the two types of cases, especially between unit-determinations and duty to bargain cases, is an argument against such a division, but the difficulties involved are not insurmountable.

182. See, e.g., the requirement of a hearing prior to an election, embodied in $\S 9$ (c). If a representation ease does not involve an issue as to effect on commerce, the appropriate unit, or bars to conducting the election, the insistence on a hearing is often a wholly dilatory tactic. Unnecessary delays might be avoided without undue curtailment of private rights by reverting to the Wagner Act practice of affording only the right to a postelection hearing in such cases. 
authority of its judgments. The tensions resulting from the lawless opposition to integration in education underscore the need for Congress to reduce the number of sensitive and broad judgments which the Court must make concerning matters which are not controlled by the Constitution but which are subject to congressional action. Perhaps these considerations, together with the anomaly of the no man's land, will move Congress to face the intellectual, political, and practical difficulties raised by legislation which would occupy the no man's land and which would also provide clearer guides for an adjustment of federal and state power in the entire area of labor relations.

Pending such action, Guss will complicate jurisdictional determinations by state agencies. State power theoretically extends only to an ill-defined category of enterprises which do not "affect commerce." The Court has indicated that contacts with interstate commerce which are more substantial than de minimis are a sufficient predicate for the exercise of the national power. ${ }^{183}$ The Court has, moreover, made it clear that the existence of national power is not to be determined solely by the quantitative effect of the activities under litigation. "Appropriate for judgment is the fact that the immediate situation is representative of many others throughout the country, the total incidence of which if left unchecked may well become far-reaching in its harm to commerce." 184 But there are practical limits to the all-encompassing national power implicit in this approach. "Scholastic reasoning may prove that no activity is isolated within the boundaries of a single State, but that cannot justify absorption of legislative power by the United States over every activity."185 Precisely where scholastic reasoning ends and a functional approach begins has necessarily been left open. More concretely, the labor cases in which the Court has delineated the broad reach of the commerce power have not involved the "small" (or the "very small") retailers ${ }^{186}$ and service establish-

183. NLRB v. Denver Bldg. Trades Council, 341 U.S. 675, 684-85 (1951).

184. Polish Nat'l Alliance v. NLRB, 322 U.S. 643, 648 (1944) (Frankfurter, J.).

185. Id. at 650 . Compare, however, the argument recently made by the Board's General Counsel :

Finally, the Supreme Court has ruled that the federal power over commerce-which is co-extensive with the coverage of the National Act-reaches the wheat grown by a single farmer for his ozem consumption (Wickard v. Filburn, 317 U.S. 111), and a retail druggist who removes 12 tablets from their out-of-state container and places them in his own box for local sale. U.S. v. Sullivan, 332 U.S. 690 , 697-98.

Brief for NLRB, p. 11, NLRB v. New York State Labor Relations Bd., 99 F. Supp. 526 (S.D.N.Y. 1951), quoted in Feldblum, Jurisdictional "Tidelands" in Labor Relations, 3 LAB. L.J. 114, 117 (1952).

186. See Guss and its two companion cases, Amalgamated Meat Cutters, AFL v. Fairlawn Meats, Inc., 353 U.S. 20 (1957); San Diego Bldg. Trades Council v. Garmon, 353 U.S. 26 (1957), for illustrations of enterprises, including retailers, which were not "large" but were large enough to "affect commerce." See also Howell Chevrolet Co. v. NLRB, 346 U.S. 482 (1953), sustaining the applicability of the LMRA to a Chevrolet dealer franchised by General Motors, purchasing $\$ 1,000,000$ annually from GM, $43 \%$ of which was manufactured out of state. Mr. Justice Douglas dissented without opinion. 
ments which are loosely considered to be "local." Whether the Court will now validate state regulation of such enterprises is wholly conjectural. But the persistence of the no man's land will invite a vigorous and perhaps, in constitutional terms, an over-vigorous exercise of state power ${ }^{187}$ as the only method of shrinking the regulatory vacuum. It may also invite the Court, by denial of certiorari, to disregard theoretical state encroachments in this area.

Part II of this article, which will appear in the February issue, will discuss the allocation of jurisdiction over the enforcement of collective bargaining agreements.

187. For a survey of recent jurisdictional determinations by state agencies see Hays, State Courts and Federal Premption, 23 Mo. L. Rev. 373, 388-94 (1958). 